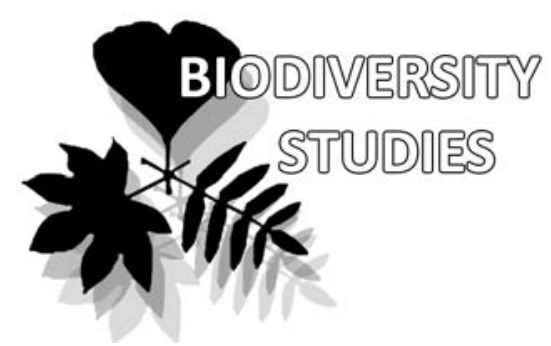

\title{
Moss flora of Zeysky State Nature Reserve (Tukuringra Range, Amur Province, Russia)
}

\author{
Sergey V. Dudov ${ }^{1,2 *}$, Mikhail N. Kozhin ${ }^{1}$, \\ Vladimir E. Fedosov ${ }^{1}$, Elena A. Ignatova ${ }^{1}$, Michael S. Ignatov ${ }^{1,3}$
}

\section{Sergey V. Dudov ${ }^{1,2 *}$ \\ e-mail: serg.dudov@gmail.com \\ Mikhail N. Kozhin ${ }^{1}$ \\ e-mail: mnk_umba@mail.ru \\ Vladimir E. Fedosov ${ }^{1}$ \\ e-mail: fedosov_v@mail.ru \\ Elena A. Ignatova ${ }^{1}$ \\ e-mail: arctoa@list.ru \\ Michael S. Ignatov ${ }^{1,3}$ \\ e-mail: misha_ignatov@list.ru}

${ }^{1}$ Lomonosov Moscow State University, Faculty of Biology, Geobotany Dept., Moscow 119234 Russia

${ }^{2}$ Zeysky State Nature Reserve, Zeya, Amur Province 676246 Russia

${ }^{3}$ Tsitsin Main Botanical Garden RAS, Moscow 127276 Russia

* corresponding author

Manuscript received: 03.10 .2018 Review completed: 16.10 .2018

Accepted for publication: 23.10.2018

Published online: 24.10.2018

\begin{abstract}
A B S T R A C T
An annotated list of the moss flora of Zeysky Nature Reserve is presented. It includes 310 species, with 140 species newly recorded for the reserve and 25 species new for Amur Province, including two species, Hondaella caperata and Hyopbila involuta from the Red Data Book of Russian Federation. Other interesting records include recently described species (Amphidium asiaticum, Hedwigia kuzenevae, Sphagnum mirum), species on the western border of their distribution (Cryphaea amurensis, Dicranum pacificum, Hondaella caperata, Leucodon coreensis and Stereodon calcicola), on the southern edge of its distribution (Psilopilum cavifolium) and rare species with scattered localities in the southern Far East (Hyophila involuta, Seligeria donniana). A comparison with other moss floras in Asian Russia of about the same area indicates that the moss flora of Zeisky Reserve is more similar to other floras of the Amur River basin and also to Transbaicalian floras, rather than to the floras of Primorsky Territory, as the latter is much more enriched by East Asian flora elements.
\end{abstract}

K e y w o r d s : moss, phytogeography, altitude zonation, Far East, Zeysky Reserve

\section{P E 3 Ю M E}

Аудов С.В., Кожин М.Н., Федосов В.Э., Игнатова Е.А., Игнатов М.С. Мхи Зейского заповедника (хребет Тукурингра, Амурская обцасть, Россия). Представлен аннотированный список мхов Зейского заповедника, в котором обобщены ранее известные Аанные и собранные авторами материалы; он вкАючает 310 видов, из которых 140 впервые приводятся Аля территории заповедника и 25 виАов являются новыми Аля Амурской области, в числе которых Hondalla caperata и Hyophila involuta, вкАючены в Красную книгу России. Интерес представ яют находки недавно описанных видов (Amphidium asiaticum, Hedwigia kuzenevae, Sphagnum mirum) видов, находящихся на западной границе ареала (Cryphaea amurensis, Dicranum pacificum, Hondaella caperata, Leucodon coreensis, Stereodon calcicola), вида с более северным распространением, найленного в Амурской области в отрыве от основного ареала (Psilopilum cavifolium), редких видов с рассеянными местонахождениями на юге Российского Аальнего Востока (Hyophila involuta, Seligeria donniana). Сравнение с флорами мхов других территорий азиатской России сходного размера показывает, что фмора мхов Зейского заповедника по своему составу ближе к флорам Приамурья, в том числе Верхнего (на территории Забайкальского края), нежели к флоре Приморского края, которая сильно обогащена восточноазиатскими виАами.

КАючевые слова: мхи, ботаническая география, высотная поясность, Аальний Восток, Зейский заповедник

\section{INTRODUCTION}

Zeysky Nature Reserve is situated in the eastern part of the Tukuringra Range in Amur Province. Its area comprises the north-western limit of broad-leaved forests of Quercus mongolica Fisch. ex Ledeb. and Tilia amurensis Rupr., which occur here side by side with East Siberian continental taiga. Dahurian steppe species reach their eastern limit here, with the western border of Okhotian flora elements, associated with Picea ajanensis (Lindl. \& Gordon) Fisch. \& Carr. "dark taiga" vegetation, extending into the reserve. This phytogeograpic hotspot contributes to an outstanding diversity of the vascular plant flora (Kuzeneva 1920, Sochava 1957, Gubanov et al. 1981).
Exploration of the moss flora of Tukuringra Range started at the beginning of the 20th century, when O.I. Kuzeneva and N.I. Prokhorov collected mosses in this area in 1909 and 1910 during the Amur expedition of the Resettlement Administration of Russian Empire. However, all collections from those years, identified by V.F. Brotherus and published by Brotherus et al. (1916), were made outside the reserve territory, mostly in the more western parts of the range. Later, in 1914 and 1915, Kuzeneva and Prokhorov collected specimens from the Zeya River along the reserve border and within the reserve territory, in the valley of Bol'shaya Erakingra Creek. These collections are mainly kept in $\mathrm{H}$ and LE, with some duplicates in MW and 
MHA; only a few of them were published, however, mostly as a result of re-examination of specimens during later taxonomic revisions of some genera (Jamieson 1976, Ignatov \& Cherdantseva 1995, Ignatova \& Muñoz 2004, Ignatova et al. 2015, 2017).

Later, in 1972-1974, S.K. Gambaryan (1977, 1978a, $1978 \mathrm{~b}$ ) studied the moss flora of the newly (in 1963) organized Zeysky Reserve and listed 99 species; her collections are deposited mostly in VLA, with some duplicates in MW, MHA and IRK. Expeditions from Lomonosov Moscow State University have conducted studies of the biodiversity in Zeysky Reserve since 1976, and mosses have been collected by its participants: I.A. Gubanov (1976-1977), M.S. Ignatov (1977), D.A. Petelin (1977-1985 and in 1989 with B.F. Khasanov), K.L. Tarasov (1979) and L.I. Abramova (1980). These collections are deposited in MW, MHA and the herbarium of Zeysky Reserve. Based on them, two annotated lists were published (Abramova \& Petelin 1981, Abramova et al. 1987). The latter includes 199 moss species and is still the most comprehensive source on the moss flora of the reserve; however, some records from this list are not confirmed by herbarium specimens in MW.

In 1991-1994 O.G. Barinov and M.A. Barinova studied bryophyte ecology in Zeisky Reserve, in Gilui River valley (Barinova 1997); their small collections are stored in Zeysky Reserve.

However, despite such a long history of bryofloristic exploration in the reserve territory, field work by the senior author in 2012-2016 (in 2013-2014 with K.V. Kotelnikova, in 2016 with M.N. Kozhin) has revealed many species that have not been previously recorded (collections in MW). Altogether, some 2000 specimens were studied. About half of them were gathered from the 350 vegetation relevés recorded to describe the vegetation of the reserve and its buffer zone. Some areas appeared to be more diverse in bryophytes, and mosses in such interesting sites were additionally collected; these places are shown in Fig. 1. and Table 1. The main collection is deposited in MW and label information is available in the database of the Moss Flora of Russia (Ivanov et al. 2017). Some of the more interesting records have already been published by Dudov et al. (2015a, 2015b, 2016). The aim of the present paper is to summarize all available data on the moss flora of Zeysky Nature Reserve and to discuss its phytogeographical position and species diversity.

\section{STUDY AREA}

Zeysky Nature Reserve occupies an area of $994 \mathrm{~km}^{2}$ (1206 $\mathrm{km}^{2}$ including its partly protected buffer zone) in the eastern part of Tukuringra Range (Fig. 1). The range is an asymmetrical horst with an elevational range of $800-1400 \mathrm{~m}$. The bedrock is diverse, with a prevalence of Proterozoic rocks: biotite and hornblende gneisses, amphibolites and schist. Proterozoic formations are intersected by a belt of slightly metamorphosed Late Jurassic-Early Cretaceous consertal sandstones, siltstones and conglomerates, which are common on the southern flanks of the mountain range. Proterozoic and Mesozoic intrusions of acidic composition are also common. Outcrops of metamorphic limestone in the Izvestkovyi Klyuch valley are noteworthy.



Figure 1 Collecting localities in Zeysky Nature Reserve: a - most interesting collection sites cited in checklist and in Table $1 ; \mathrm{b}-$ other author's collection localities; c - border of Zeysky Reserve

The topography is typified by deeply incised valleys, 250-660 $\mathrm{m}$ in depth (Gotvanskiy 1968), often with cliffs along steep banks. Upper elevations at 1100-1442 $\mathrm{m}$ are usually flat, comprising mountain tundra and rock fields with some rock pillars; at lower elevations mountain watersheds are either rounded, or sharply angular. Rock fields are common on steep slopes at all elevations.

The climate of the study area is cold temperate, characterized by a combination of monsoon influences and pronounced continentality due to cold winters. The average annual temperature according to the Zeya meteostation at the foothills of the mountains is $-0.9^{\circ} \mathrm{C}$, while our short term observations found it to be $+1.5^{\circ} \mathrm{C}$ in Zeya River valley at 
Table 1. Major collection sites within Zeysky State Nature Reserve.

\begin{tabular}{|c|c|c|c|c|}
\hline $\mathbf{N}$ & Locality & Main habitats & Altitude, $\mathrm{m}$ a.s.l. & Coordinates, WGS84 \\
\hline 1 & vicinity of cordon "Teplyi Kluch" & $\begin{array}{l}\text { larch-birch, black birch and oak forests, rock } \\
\text { outcrops }\end{array}$ & $315-400$ & $53^{\circ} 51^{\prime} \mathrm{N} 127^{\circ} 20^{\prime} \mathrm{E}$ \\
\hline 2 & valley of the Izvestkovyi Klyuch & limestone rocks and outcrops & $315-350$ & $53^{\circ} 53^{\prime} \mathrm{N} 127^{\circ} 23^{\prime} \mathrm{E}$ \\
\hline 3 & $\begin{array}{l}\text { bank of the Zeya reservoir between } \\
\text { the Razvedochny and Sukhoy gulfs }\end{array}$ & $\begin{array}{l}\text { birch-larch, mongolian oak forests, rock } \\
\text { outcrops }\end{array}$ & $315-380$ & $53^{\circ} 51^{\prime} \mathrm{N} 127^{\circ} 23^{\prime} \mathrm{E}$ \\
\hline 4 & vicinity of cordon "20th km" & larch-birch forest & 500 & $53^{\circ} 52^{\prime} \mathrm{N} 127^{\circ} 06^{\prime} \mathrm{E}$ \\
\hline 5 & $\begin{array}{l}\text { the Bol'shaya Erakingra valley, the } \\
\text { vicinity of the cordon " } 52 \text { th } \mathrm{km} "\end{array}$ & $\begin{array}{l}\text { forests in valley and at the slopes, pebbles } \\
\text { near the streams }\end{array}$ & $600-700$ & $54^{\circ} 5^{\prime} \mathrm{N} 126^{\circ} 53^{\prime} \mathrm{E}$ \\
\hline 6 & $\begin{array}{l}\text { the main watershed of the ridge in the } \\
\text { upper Motovaya River }\end{array}$ & $\begin{array}{l}\text { spruce forests, Pinus pumila elfinwoods, } \\
\text { sparse Betula lanata woodlands, subalpine } \\
\text { meadows and bogs, tundras }\end{array}$ & $1350-1440$ & $54^{\circ} 08^{\prime} \mathrm{N} 126^{\circ} 56^{\prime} \mathrm{E}$ \\
\hline 7 & $\begin{array}{l}\text { vicinity of cordon "Nizhny } \\
\text { Chimchan" }\end{array}$ & sphagnum bogs, floodplain meadows, cliffs & $350-500$ & $53^{\circ} 52^{\prime} \mathrm{N} 127^{\circ} 7^{\prime} \mathrm{E}$ \\
\hline 8 & $\begin{array}{l}\text { the right side of the Gilui River Valley } \\
\text { opposite of Chapovskaya sandspit }\end{array}$ & $\begin{array}{l}\text { cliffs and rock outcrops rich in calcium } \\
\text { compounds }\end{array}$ & $320-340$ & $54^{\circ} 15^{\prime} \mathrm{N} 126^{\circ} 54^{\prime} \mathrm{E}$ \\
\hline 9 & $\begin{array}{l}\text { right side of the Gilui River valley } \\
\text { below the mouth of Shirokaya River }\end{array}$ & gneiss rocks and rock outcrops, screes & $320-400$ & $54^{\circ} 14^{\prime} \mathrm{N} 126^{\circ} 56^{\prime} \mathrm{E}$ \\
\hline 10 & $\begin{array}{l}\text { lake on the watershed surface among } \\
\text { Shirokaya (Stepanak) and Zolotoi } \\
\text { valleys }\end{array}$ & sedge-sphagnum peatbog & 383 & $54^{\circ} 13^{\prime} \mathrm{N} 126^{\circ} 57^{\prime} \mathrm{E}$ \\
\hline 11 & $\begin{array}{l}\text { left bank of the Gilui River upstream } \\
\text { from the mouth of the Zolotoy spring }\end{array}$ & base-rich rock outcrops & 350 & $54^{\circ} 14^{\prime} \mathrm{N} 126^{\circ} 57^{\prime} \mathrm{E}$ \\
\hline 12 & $\begin{array}{l}\text { bank of the Zeya Reservoir near the } \\
\text { cordon «Izubriny» }\end{array}$ & $\begin{array}{l}\text { meadows, degraded bogs and birch-larch } \\
\text { forest in the underflooding zone }\end{array}$ & $315-320$ & $54^{\circ} 12^{\prime} \mathrm{N} 127^{\circ} 0^{\prime} \mathrm{E}$ \\
\hline 13 & the «Chertova Pechka» cliff & gneiss rocks and outcrops & $320-340$ & $54^{\circ} 13^{\prime} \mathrm{N} 126^{\circ} 59^{\prime} \mathrm{E}$ \\
\hline 14 & $\begin{array}{l}\text { valley of the Motovaya River } 1.5 \mathrm{~km} \\
\text { upstream from the modern mouth }\end{array}$ & $\begin{array}{l}\text { rocky slopes with black birch forests and } \\
\text { rock outcrops }\end{array}$ & $330-400$ & $54^{\circ} 5^{\prime} \mathrm{N} 127^{\circ} 12^{\prime} \mathrm{E}$ \\
\hline 15 & $\begin{array}{l}\text { the Tabuneika River valley near its } \\
\text { mouth }\end{array}$ & $\begin{array}{l}\text { valley forests, meadows in the underflooding } \\
\text { zone of reservoir, outcrops }\end{array}$ & $330-380$ & $54^{\circ} 3^{\prime} \mathrm{N} 127^{\circ} 20^{\prime} \mathrm{E}$ \\
\hline
\end{tabular}

$330 \mathrm{~m}$ alt. and $-6.5^{\circ} \mathrm{C}$ at $1000 \mathrm{~m}$ (Dudov 2016). The coldest month is January with average temperature $-24.2^{\circ} \mathrm{C}$. Mean annual precipitation in the foothills is $530 \mathrm{~mm}$, while in the mountains it is two to three times greater. Permafrost covers $70-80 \%$ of the study area (Nekrasov \& Klimovskiy 1978). In narrow and deep valleys, aufeises up to 4-5 m thick are formed, lasting up to July and in places even into August.

The vegetation of Tukuringra Range was subdivided into five main altitudinal belts (Golysheva et al. 1980): (1) lowermost Quercus mongolica-Betula davurica Pall. belt (only near Zeya, up to $500 \mathrm{~m}$ ); (2) Larix gmelinii (Rupr.) Rupr. forest belt up to $900 \mathrm{~m}$; (3) Picea ajanensis belt (900-1100 m); (4) Pinus pumila (Pall.) Regel thickets (1100-1300 m) and Betula lanata (Regel) V.N. Vassil. krummholz; (5) mountain tundra belt above $1100 \mathrm{~m}$. However, as belts $2 \& 3$ and $4 \& 5$ can overlap spatially, both in terms of species composition and plant communities, three further subdivisions are considered:

Hemiboreal belt, 315-500 m, mainly on slopes to the Zeya River, formed by stands of broad-leaved trees, Betula davurica and hemiboreal larch forests enriched by temperate East Asian species.

Boreal belt, 315-1300 m, with larch forests (especially up to $1000 \mathrm{~m}$ ), comprised of shrubby (with Rhododendron dauricum L.), grassy (with Calamagrostis purpurea (Trin.) Trin.) and cowberry (Vaccinium vitis-idaea L.) types, mires with Ledum palustre L., and moss-dominated types. In river valleys, there are poplar (Populus suaveolens Fisch.) and Chose- nia arbutifolia (Pall.) A.K. Skvortsov stands. Picea ajanensis occurs throughout the boreal belt, but it forms spruce forest, usually with a continuous moss carpet, only in upper subbelt of the boreal belt (900-1300 m).

Subalpine belt at 1100-1442.8 m with krummholz, Pinus pumila elfinwoods, and mountain tundras, with Rhododendron parvifolium Adams, Salix sphenophylla A.K. Skvortsov, Diapensia obovata (F. Schmidt) Nakai, Vaccinium uliginosum L., lichens (Cladonia rangiferina (L.) F. H. Wigg., Cetraria laevigata Rass., Alectoria ochroleuca (Hoffm.) A. Massal., Asabinea chrysantha (Tuck.) W. L. Culb. \& C. F. Culb.) and mosses (Aulacomnium turgidum, Sphagnum lenense, $S$. divinum).

The reserve territory is surrounded on its eastern and northern borders by the Zeya Water Reservoir, filled up in 1964-1980, with the dam of the Zeya Power station $110 \mathrm{~m}$ high. The current level of the Zeya Water Reservoir, at $315 \mathrm{~m}$ elevation, is ca. $60 \mathrm{~m}$ above the previous level of the Zeya River, and the lower parts of small creeks, the Zeya River tributaries (called here mostly as "klyuch") were drowned when the reservoir was filled.

\section{Main habitats of mosses}

The main groups of habitats can be characterized by their most common species and by some species confined to respective belt as follow:

In oak-black birch forest, mosses grow mainly on tree trunks, e.g. Platygyrium repens, Pylaisia falcata, P. polyantha, P. selwynii, Lewinskya sordida, Haplocladium angustifolium, 


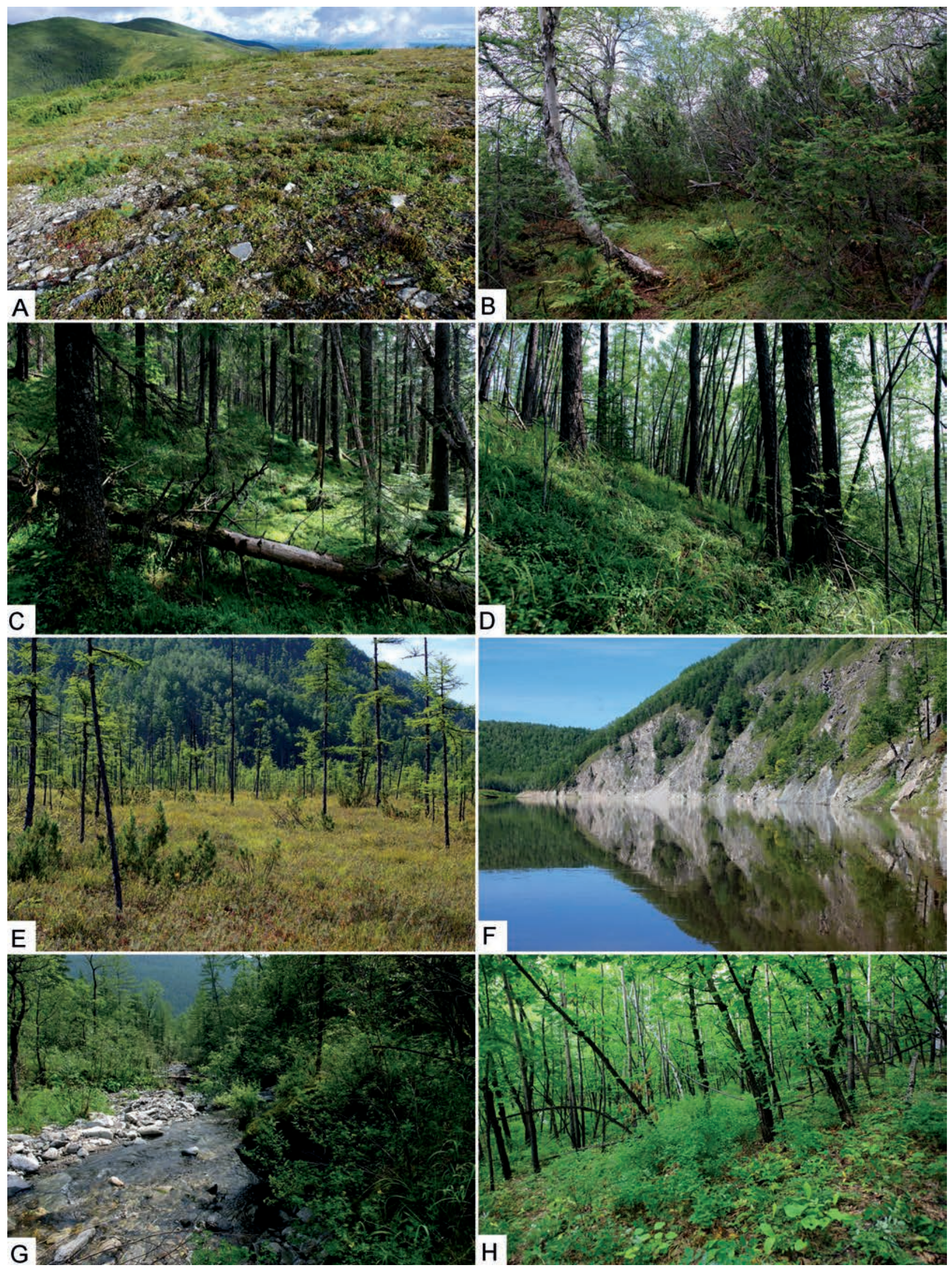

Figure 2 Major habitat types of Zevsky Reserve. A - Tundra with dwarf shrubs (Rhododendron parvifolium, Salix sphenophylla, Vaccinium uliginosum) at the main watershed of Tururingra Range in the upper course of Motovaya River, $1380 \mathrm{~m}$ a.s.l. B - Sparse Betula lanata woodland, $1370 \mathrm{~m}$ a.s.l. C Spruce forest (Picea ajanensis) in the upper course of Valunnyi Klyuch, $1350 \mathrm{~m}$ a.s.l. D - Larch forest (Larix gmelinii) with well developed herb layer at the southern slope, $700 \mathrm{~m}$ a.s.l. E -Sparse boggy larch woodland in the Nizhnyi Chimchan River valley, $380 \mathrm{~m}$ a.s.l. F - Calcareous rock outcrops 
Leptodontium flexifolium, while on roots and at trunk bases Bracbythecium buchananii, Bryoerythrophyllum recurvirostrum, Homomallium incurvatum and Myuroclada maximowiczii occur.

Moss cover in larch and spruce taiga is formed by Dicranum japonicum, D. polysetum, Eurbynchiastrum pulchellum, Hylocomium splendens, Plagiothecium laetum, Pleurozium schreberi, Polytrichum commune, Polytrichastrum alpinum, Ptilium crista-castrensis and Sphagnum girgensohnii. Rhytidium rugosum and Abietinella abietina are abundant on drier and more exposed slopes. On fallen trunks, Brothera leana, Campylidium sommerfeltii, Dicranum fragilifolium, D. fuscescens, Oncophorus wablenbergii, Plagiomnium cuspidatum, Plagiothecium laetum, Pylaisiadelpha tenuirostris, Tetraphis pellucida, Sanionia uncinata, Sciuro-hypnum curtum, Stereodon pallescens and S. plicatulus are commonly found. On trunk bases, Abietinella abietina, Brachythecium buchananii, B. rotaeanum, Callicladium haldanianum, Thuidium assimile and Dicranum montanum occur. Pylaisiadelpha tenuirostris, Dicranum montanum and $D$. flagellare usually grow on larch trunks, while Iwatsukiella leucotricha is characteristic of spruce trunks and twigs. Wet spruce forests in valleys are rich in epiphytes: Leucodon pendulus, L. sciuroides and Neckera pennata often grow on spruce, while Lewinskya iwatsukii, L. sordida, L. transcaucasica, Nyholmiella obtusifolia, Pylaisia falcata, P. polyantha, P. steerei, Ulota rebmannii and Zygodon sibiricus are mostly confined to deciduous trees. Pylaisia selaynii and Brachythecium dahuricum are found predominantly on aspen. After fire events, Ceratodon purpureus, Dicranum montanum and Aulacomnium turgidum are the first to colonise charred tree trunks, while on soil Polytrichum juniperinum forms extensive communities.

In the valley forests, Climacium dendroides, Rhytidiadelphus triquetrus, Rhodobryum ontariense, Sphagnum teres, S. tundrae and S. squarrosum are common on wet rich soil, while Amblystegium serpens, Atrichum flavisetum, Funaria hygrometrica, Poblia andrewsii, Saelania glaucescens and Schistostega pennata can be found under upturned roots of fallen trunks. On sandy and silty alluvium in floodplains, Brachythecium rivulare, Bryum pseudotriquetrum, Dichodontium pellucidum, Calliergonella lindbergii, Niphotrichum panschii, Oncophorus virens, Philonotis fontana, Poblia andalusica and P. filum occur. Didymodon zanderi is associated with tree trunks covered with silt deposits. In the temporarily exposed draw-down zone of the water reservoir and on the degraded bogs in the area of its influence, Atrichum tenellum, A. undulatum, Poblia andalusica, P. andrewsii, P. annotina, P. bulbifera, P. proligera and Trichodon cylindricus are found.

On rocks in brooks, Calliergon cordifolium, C. giganteum, Warnstorfia sarmentosa, Blindia acuta, Hygrobypnella ochracea and $H$. polaris are most common at lower elevations. Wet cliffs near brooks are often covered by Dichodontium pellucidum and Blindia acuta.

In open larch forests with sphagna, Sphagnum girgensobnii and S. lenense dominate; Helodium blandowii, Polytrichum strictum, P. swartrii and Tomenthypnum nitens occur occasionally. Sphagnum jensenii, S. lindbergii, S. obtusum, Warnstorfia exannulata and $W$. fluitans grow in hollows on mires in the Gilui River valley.
On rock fields in the hightest altitudinal belt, Andreaea rupestris, Cynodontium asperifolium, Dicranum schliakovii, D. spadiceum, Eurbynchiastrum pulchellum and Niphotrichum canescens are the most common species while on dry rock outcrops in the boreal and hemiboreal belts, Abietinella abietina, Anomodon minor, Grimmia pilifera, G. longirostris, Hedwigia spp. and Schistidium pulchrum are common.

In shaded niches and cliff crevices, Amphidium mongeotii, Anoectangium thomsonii, Encalypta ciliata, Homomallium connexum, Oxystegus tenuirostris, Rhabdoweisia crispata, Mnium thomsonii, Homalia trichomanoides, Distichium capillaceum, Isopterygiopsis alpicola, Myurella julacea and Myuroclada maximowiczii are found.

On calcareous rocks in the valley of Izvestkovyi Klyuch (the only limestone outcrops in the reserve), Anomodon thraustus, Bartramia ithyphylla, Cyrtomnium bymenophylloides, Brachythecium cirrosum, Campyliadelphus chrysophyllus, Cratoneuron filicinum, Didymodon ferrugineus, Entodon concinnus, Gymnostomum aeruginosum, Hymenostylium recurvirostrum, Molendoa sendtneriana, Myurella julacea, Timmia bavarica and T. comata occur.

On soil in the subalpine belt, taiga species such as Ptilium crista-castrensis and Pleurozium schreberi, as well as Aulacomnium palustre, Dicranum bardunovii and Hypnum cupressiforme grow in elfinwood thickets. In dwarf shrub tundra, Abietinella abietina, Dicranum elongatum, Polytrichum piliferum and Rhytidium rugosum are common. In moss tundras, ground cover is formed by Aulacomnium turgidum, Dicranum elongatum, D. groenlandicum, D. schljakovii, Polytrichum strictum, Sphagnum balticum, S. compactum, S. lenense and S. divinum; on rock outcrops at this elevation Bucklandiella microcarpa, B. sudetica, Cynodontium strumiferum, Grimmia jacutica and G. longirostris occur.

\section{LIST OF SPECIES}

As the most complete data on the reserve moss flora were published by Abramova et al. (1987), it is always cited for species reported in it as "[Abr 1987]". Some other publications are cited where relevant. Taxa new for Zeysky Reserve are marked with "+". Species recorded by Abramova et al. (1987), but not confirmed by specimens in MW or MHA, are included in the list with "-" before species name (these are mostly widespread species, known from neighboring areas). However, most unconfirmed species are not included in the main list of species, but enumerated and discussed after it.

Species are annotated by the altitudinal range [in brackets]; occurrence in three vegetation belts, given as abbreviations, i.e. SA: subalpine, B: boreal and HB: hemiboreal; habitats and frequency are given separately for each of these belts; frequency is abbreviated as follow: $\mathrm{Un}$ - unique; $\mathrm{Rr}$ - rare; Sp - sparse; Fr - frequent; Com - common; associated species and other comments are given where relevant.

The nomenclature follows Cherdantseva et al. (2018).

Abietinella abietina (Hedw.) M. Fleisch. - [Abr 1987] [300-1351 m] SA: dwarf shrub and dwarf shrub-moss tundras, on soil among Rhytidium rugosum. Rr. B: in larch

on the left bank of the Gilui River upstream from the mouth of the Zolotoy Klyuch, $350 \mathrm{~m}$ a.s.l. G - the floodplain of small brook on the right tributary of Bol'shaya Erakingra Creek with pebble-bed, pioneer willow (Salix udensis, S. cardiophylla) communities and sparse larch forests, $650 \mathrm{~m}$ a.s.l. $\mathrm{H}$ - Oak forest with Lespedeza bicolor in shrub layer in the vicinity of cordon "Teplyi Klyuch", $370 \mathrm{~m}$ a.s.l. Photo by: S.V. Dudov 2012-2016 
and small-leaved forests, rarer in spruce forests, more often on southern slopes; on soil, trunk bases, rocks. Fr. HB: in small-leaved and oak-Betula davurica forests; on soil, trunks and cliffs. Com.

Amblystegium serpens (Hedw.) Bruch, Schimp. \& W. Gümbel - [Abr 1987] [320-650 m] B: on soil under upurned roots of fallen trees, base-rich cliffs, birch trunk bases, logs and soil. Rr. For our territory, Amblystegium serpens var. juratrkanum (Schimp.) Rau \& Herv is also listed.

+ Amphidium asiaticum Sim-Sim, Afonina \& M. Stech - [465 m] B: cliffs at the left border of Gilui Bay, opposite Tabuneika River Bay, and on the left bank of the Gilui River opposite Nizhny Chimchan River mouth. Rr. Described from Mongolia (Sim-Sim et al. 2017), known from a few localities in Transbaikalia in Zabaikalsky Territory and the Republic of Buryatya (Afonina et al. 2017). New to Amur Province.

Amphidium lapponicum (Hedw.) Schimp. - [Abr 1987$]$ [350-645 m] B: cliffs in the upper course of the Motovaya River. HB: rock outcrops on the south-eastern slope near cordon "Teplyi klyuch". Rr.

+ Amphidium mougeotii (Bruch \& Schimp.) Schimp. - [330-450 m] B \& HB: in crevices and shaded niches of schist cliffs rich in calcium. Sp.

Andreaea rupestris Hedw. - [Abr 1987] [320-1376 m] SA: rock pillars, cliffs, and rock fields. Sp. B: stone fields, rocks in brooks. Rr.

+ Anoectangium thomsonii Mitt. (= Anoectangium stracheyanum Mitt.) - [320-450 m] B \& HB: on wet gneiss, schist, and limestone cliffs. Sp. Often forms extensive pure mats.

+ Anomobryum concinnatum (Spruce) Lindb. - [322$345 \mathrm{~m}]$ B: cliffs on the left bank of the Gilui River upstream of Zolotoy Klyuch mouth, on the "Chertova Pechka" cliff, in rock crevices with seeping water. Rr. The species was known in Amur Province from Norsky Nature Reserve (Czernyadjeva et al. 2015), it was also found on Tokinsky Stanovik (Stepanova et al. 1995).

+ Anomobryum nitidum (Mitt.) A. Jaeger - [345 m] B: on cliffs on the left bank of Gilui River upstream Zolotoy Klyuch mouth, rock crevices with seeping water. Un. New to Amur Province. Known from South-Eastern Transbaikalia, Southern Primorye, Commander and Kuril Islands (Czernyadjeva et al. 2015, Bakalin et al. in press).

Anomodon minor (Hedw.) Fürnr. - [Abr 1987] [315$690 \mathrm{~m}] \mathrm{B} \& \mathrm{HB}$ : dry cliffs and rock outcrops. Fr.

Anomodon thraustus Müll. Hal. - [320-470 m] B \& HB: dry shaded cliffs. Sp.

Atrichum flavisetum Mitt. - [Abr 1987] [320-500 m] B: on fine soil under cliff overhangs, on soil under upturned roots of fallen trunks in forests. Rr.

+ Atrichum tenellum (Röhl.) Bruch, Schimp. \& W. Gümbel $-[317 \mathrm{~m}]$ B: bank of the Gilui Bay of the Zeya Reservoir near the "Izubriny" cordon, Calamagrostis meadow in the draw-down zone of the water reservoir. Un. Predominantly a European species, with scattered localities east of Baikal (Afonina et al. 2017; Cherdantseva et al. 2018). New to Amur Province.

+ Atrichum undulatum (Hedw.) P. Beauv. - [317-320 m] B: on soil in degraded forests in the area of water reservoir influence, on fine soil in temporary stream beds. All findings in vicinity of cordon "Izubriny". Rr.

Aulacomnium palustre (Hedw.) Schwägr. - [Abr 1987] [320-1435 m] SA: on soil in moss and dwarf shrub-moss tundras, in elfinwood communities. Fr. B: in Sphagnum bogs and boggy larch forests; in shrub communities along brooks; on soil, trunk bases, and on fallen logs in larch and secondary forests, often in burnt areas. Fr. We also collected Aulacomnium palustre var. imbricatum Bruch \& Schimp.: near cordon " $20 \mathrm{th} \mathrm{km}$ ", on soil in birch and larch forest with Calamagrostis and Vaccinium vitis-idaea.
Aulacomnium turgidum (Wahlenb.) Schwägr. - [Abr 1987] [320-1400 m] SA: in moss and dwarf shrub-moss tundras where it dominates, in elfinwood communities. Com. B: in sparse larch forests with Sphagnum, in Sphagnum bogs. The species grows as a pioneer on charred trunks and stumps in burnt forest areas. Sp.

+ Bartramia ithyphylla Brid. - [320-340 m] B: gneiss outcrops on the right slope of the Gilui River valley opposite Chapovskaya sandspit, marble outcrops on the right bank of the Gilui Bay of the Zeya Reservoir above the mouth of Mrachnyi Klyuch. Rr.

Bartramia pomiformis Hedw. - [Abr 1987] [326-670 m] B: on soil, rock outcrops, logs in larch and birch forests, on rocks in stone fields. Sp.

Blindia acuta (Hedw.) Bruch, Schimp. \& W. Gümbel [Abr 1987] [326-768 m] B: on cliffs near watercourses, on rocks in temporary stream beds and oxbows in floodplains. Sp.

+ Brachytheciastrum trachypodium (Brid.) Ignatov \& Huttunen - $[350 \mathrm{~m}] \mathrm{B}$ : between rocks in stone rivers at the right slope of the Gilui River valley below the mouth of Shirokaya River. Un.

+ Brachythecium buchananii (Hook.) A. Jaeger - [320$500 \mathrm{~m}]$ B \& HB: on tree trunks, fallen logs and rocks in larch and deciduous forests. Sp.

+ Brachythecium cirrosum (Schwägr.) Schimp. - [320$400 \mathrm{~m}]$ B \& HB: on gneiss cliffs opposite Nizhny Chimchan River mouth, on cliffs of metamorphosed limestone in the valley of Izvestkovyi Klyuch. Rr.

+ Brachythecium daburicum Ignatov - [370-860 m] B \& HB: on soil, fallen logs, and trunks of aspen and willow trees on exposed slopes and floodplains. Rr.

+ Brachythecium erythrorrbizon Bruch, Schimp. \& W. Gümbel - [1350 m] SA: on soil on sedge-reed grass meadow with Rhododendron aureum at the main watershed of the ridge in the upper reaches of the Motovaya River. Un.

Brachythecium mildeanum (Schimp.) Schimp. - [Abr 1987] [320-550 m] B: on fine alluvium in narrow valley with constant brook within a cliff depression in larch forest, on soil in bird-berry thickets in floodplain of Bol'shaya Erakingra River. Rr.

+ Brachythecium rivulare Bruch, Schimp. \& W. Gümbel - [320-1300 m] B: in a microdepression in dry bed of a brook in spruce forest; on rock outcrops and soil, shaded cliff walls near watercourses, on moss-covered rock fields at bases of slopes. Rr.

+ Brachythecium rotaeanum De Not. - [320-700 m] B: on soil, fallen logs, trunk bases of birch, aspen and poplar in mixed aspen and birch-larch forests, poplar and Chosenia forests. Fr. Apparently, the most frequent species of the genus in the nature reserve.

Brachythecium salebrosum (F. Weber \& D. Mohr) Bruch, Schimp. \& W. Gümbel - [Abr 1987] [320-390 m] B: on fallen logs in floodplain spruce and mossy larch forests. Rr.

Brothera leana (Sull.) Müll. Hal. - [Abr 1987] [320$820 \mathrm{~m}] \mathrm{B}$ : on fallen logs, rarer on trunk bases of trees in forests of different types. Fr.

+ Bryoerythrophyllum cf. ferruginascens (Stirt.) Giacom. - [330 m] B: on "Chertova Pechka" cliffs in vicinity of cordon "Izubriny", with B. recurvirostrum. Un. New to Amur Province (Fedosov \& Ignatova 2011).

Bryoerythrophyllum recurvirostrum (Hedw.) P.C. Chen - [Abr 1987] [320-650 m] B \& HB: on cliffs, large rocks, where it grows together with Myurella julacea, Encalypta ciliata, Dichodontium pellucidum, Distichium capillaceum, Fissidens cf. bryoides; as well as on bark of deciduous trees: poplar and Betula davurica, predominantly in floodplain forests. Sp.

+ Bryum argenteum Hedw. - [315-500 m] HB: on exposed cliffs in valleys of Zeya and Gilui Rivers. Rr. 
Bryum creberrimum Taylor - [Abr 1987] [330-1300 m] B \& HB: on cliffs, river alluvium, exposed soil in spruce forest. Sp.

+ Bryum cyclophyllum (Schwägr.) Bruch \& Schimp. - [320 m] B: narrow valley with constant brook within a cliff depression in larch forest in the vicinity of cordon "Izubriny". Un.

+ Bryum elegans Nees - [780 m] B: on alluvium along Motovaya River in its upper course. Un.

Bryum pseudotriquetrum (Hedw.) G. Gaertn., B. Mey. \& Scherb. - [Abr 1987] [320-700 m] B \& HB: in various wet habitats in valleys: on fine soil in temporary watercourses, gravel bars, rocks and cliffs near watercourses, aufeis glades; on mire near eutrophic lake in the Gilui River valley, in Betula davurica-oak forest. Fr.

+ Bucklandiella microcarpa (Hedw.) Bedn.-Ochyra \& Ochyra - [1343-1430 m] SA: on rock pillars within dwarf shrub tundras. Rr.

+ Bucklandiella nitidula (Cardot) Bedn.-Ochyra \& Ochyra - [1370 m] SA: rock within Pinus pumila elfinwoods. $\mathrm{Rr}$. The closest known population is in Transbaikal region, in Stanovoe Upland (Afonina et al. 2017), also known from Buryatia, Kamchatka and Kuril Islands. New for Amur Province (Ignatova 2017b).

Bucklandiella sudetica (Funck) Bedn.-Ochyra \& Ochyra - [Abr 1987] [1370-1390 m] SA: on rocks within dwarf shrub tundras and Pinus pumila thickets. Rr.

Buxbaumia aphylla Hedw. - [ $1370 \mathrm{~m}]$ SA: on exposed soil of a cut soil profile. (Barinov 15.IX.1991, MW and Zeysky Reserve herbarium). Un.

Callicladium haldanianum (Grev.) H.A. Crum - [Abr 1987] [350-700 m] B: on trunk bases, fallen logs and soil in larch and secondary forests. Rr.

Calliergon cordifolium (Hedw.) Kindb. - [Abr 1987] [320-380 m] B: on soil in valley forests, in the meadow on low floodplain of the Gilui River, in water between rocks in the Motovaya River bed. Sp.

Calliergon giganteum (Schimp.) Kindb. - [Abr 1987 [320-650 m] B: on rocks along banks of streams and brooks. Sp.

Calliergon richardsonii (Mitt.) Kindb. - [Abr 1987] $[700 \mathrm{~m}] \mathrm{B}$ : on fine soil on the bank of stream - right tributary of Bol'shaya Erakingra River. Un. Reported by Abramova et al. (1987) as Sp.

+ Calliergonella cuspidata (Hedw.) Loeske - [320 m] B: iris-sedge-reed grass mire near eutrophic lake on the Gilui River terrace at the left bank of the Gilyui Bay of the Zeya Reservoir opposite Zolotoi Klyuch. Un.

Calliergonella lindbergii (Mitt.) Hedenäs - [Abr 1987] [320-650 m] B: on gravel and sandy alluvium, on soil in valley forests. Sp.

Campyliadelphus chrysophyllus (Brid.) Kanda - [Abr 1987] [320-400 m] B \& HB: on cliffs of gneiss, marble and limestone, on wet soil. Sp.

Campylophyllopsis sommerfeltii (Myrin) Ochyra - [Abr 1987 [320-760 m] B: on fallen logs, rarer on soil in forests of different types. Sp. Reported by Abramova (1987) as C. hispidulum.

+ Campylium stellatum (Hedw.) C.E.O. Jensen $[350 \mathrm{~m}] \mathrm{B}$ : on soil in valley in larch forest with Sphagnum, in Teplyi Klyuch valley. Rr.

Ceratodon purpureus (Hedw.) Brid. - [Abr 1987] [320$1380 \mathrm{~m}] \mathrm{SA}$ : on exposed soil and rock debris in tundras, reed grass meadows in late snow patches. Rr. B \& HB: on soil, fallen logs, rocks, burnt wood and cliffs of various composition. Sp.

+ Claopodium pellucinerve (Mitt.) Best - [320-1265 m] $\mathrm{B}$ : on fallen logs, rocks in forests of different types and basic cliffs. $\mathrm{Rr}$.
Climacium dendroides (Hedw.) F. Weber \& D. Mohr [Abr 1987] [330-650 m] B: on gravel bars, soil, mounds at tree trunk bases, and fallen logs in poplar, Chosenia, alder, spruce and larch forests in river valleys. Sp.

Cnestrum schisti (F. Weber \& D. Mohr) I. Hagen - [Abr 1987] [360 m] B: on cliffs on right slope of the Gilui River valley below the mouth of Shirokaya River; on rock field near the mouth of Kamrai River (Abramova et al. 1987). Rr.

+ Coscinodon cribrosus (Hedw.) Spruce - [330 m] B: on walls on "Chertova Pechka" cliffs in vicinity of cordon "Izubriny". In pure mats. Un. New for Amur Province. Closest localities of the species are known from the Republic of Buryatia and Kamchatka (Ignatova 2017a).

Cratoneuron filicinum (Hedw.) Spruce - [Abr 1987] [320-400 m] B \& HB: in places with seeping water on cliffs on the left bank of Gilui River opposite Zolotoy Klyuch; on limestone outcrops, soil in valley willow-alder forest in Izvestkovyi Klyuch, and fine soil on the bank of Teplyi Klyuch. Rr.

Cryphaea amurensis Ignatov - [380-600 m] B: on spruce twigs in valley spruce forests in floodplains of the Kamenushka River and Teplyi Klyuch, on willow branches in the forest in the valley of an unnamed brook - left tributary of the Gilui River $1.5 \mathrm{~km}$ downstream from the mouth of Nizhny Chimchan River. Rr. Previously reported by Abramova et al. (1987) as Forsstroemia trichomitria based a single specimen from Zeysky Nature Reserve and Amur Province: "Teplyi klyuch, dwarf shrub-grass spruce forest with birch. On bark of a living old elm. VIII.1979. D.A. Petelin"; this locality was subsequently flooded by Zeya Water Reservoir. Our records demonstrate that this species is significantly more widely distributed in Tukuringra Ridge. Included into the Red Data Book of Russian Federation (Ignatov 2008) under category 2.

Cynodontium asperifolium (Lindb. \& Arnell) Paris [Abr 1987] [350-1350 m] SA: on soil in dwarf shrub tundra. Un. B: on rocks on moss-covered rock fields; on soil, rocks and fallen logs in larch forests. Sp. Grows in scattered small turfs.

Cynodontium strumiferum (Hedw.) Lindb. - [Abr 1987] [420-1400 m] SA: on rock pillars, outcrops, and soil in dwarf shrub tundras. Sp. B: on rocks on large block deposit in the upper course of the Motovaya River, in larch forest in Razvedochny Klyuch valley (tributary of Gilui River). Rr.

Cynodontium tenellum (Schimp.) Limpr. - [Abr 1987] [610-1400 m] SA: on barren soil, on vertical wall of microdepression among elfinwood thicket near peak with $1442 \mathrm{~m}$ height mark (L.I. Abramova, 11.VIII.1980; MW). Un. B: on large block deposit at the right side of Izubriny Klyuch valley. Un.

+ Cyrtomnium hymenophylloides (Huebener) T.J. Kop. - [330-350 m] B \& HB: on rocks rich in calcium compounds (marble, limestone) at the right side of the Gilui River Valley opposite of Chapovskaya sandspit and in Izvestkovyi Klyuch valley. Rr.

Dichodontium pellucidum (Hedw.) Schimp. - [Abr 1987] [315-340 m] B \& HB: on cliffs, predominantly in niches on fine soils, on sandy alluvium. Sp.

Dicranella cerviculata (Hedw.) Schimp. - [Abr 1987] [600-650 m] B: on soil and roots of fallen trees, along the lake bank. $\mathrm{Rr}$.

Dicranella curvipes (Lindb.) Ignatov (D. heteromalla var. curvipes Lindb.) - [434-810 m] B: on soil and fallen logs in larch forests. Rr.

- Dicranella schreberiana (Hedw.) Hilf. ex H.A. Crum \& L.E. Anderson - [Abr 1987] in forest in Teplyi Klyuch valley. Un.

- Dicranella subulata (Hedw.) Schimp. - [Gambaryan 1977] [Abr 1987] B: on bare soil in forest belts. Rr.

Dicranum acutifolium (Lindb. \& Arnell) C.E.O. Jensen - [Abr 1987] [350-630 m] B: on soil and rocks in birch and 
larch forests. Rr. HB: on wet rotten logs in birch forest with oak. Un.

+ Dicranum bardunovii Tubanova \& Ignatova - [Abr 1987] [1320-1360 m] SA: on soil in Pinus pumila and Duschekia fruticosa thickets. Rr.

Dicranum bonjeanii De Not. - [Abr 1987] [350-1300 m] B: on soil in spruce, larch and birch-larch forests. Rr.

+ Dicranum drummondii Müll. Hal. - [955 m] B: on soil in birch-larch forest on southern slope in vicinity of the cordon "52nd km".

Dicranum elongatum Schleich. ex Schwägr. - [Abr 1987] [330-1420 m] SA: on soil in dwarf shrub and moss tundras, in Pinus pumila communities. Fr. B: on soil and fallen logs in larch forests. Sp.

Dicranum flagellare Hedw. - [Abr 1987] [330-1310 m] B: on rocks, rock outcrops, fallen logs, rarer on tree trunks in forests of various types. Fr.

Dicranum flexicaule Brid. - [Abr 1987] [380-1380 m] SA: on soil in Pinus sibirica tickets and in Betula lanata forests. Rr. B: on soil, rarer on fallen logs in spruce, larch and smallleaved forests. Sp.

Dicranum fragilifolium Lindb. - [Abr 1987] [370-950 m] B: on rotten wood, tree trunks and trunk bases, rarely on soil in larch, small-leaved and spruce forests. Fr.

Dicranum fuscescens Turner - [Abr 1987] [320-1350 m] SA: on soil in Pinus pumila thickets. Rr. B: on soil, fallen logs, trunk bases of trees in forests of different types, on rock fields. Com. One of the most common species of the genus in Zeysky Nature Reserve.

+ Dicranum groenlandicum Brid. - [1280-1340 m] SA: on soil in dwarf shrub moss tundra and sparse Betula lanata forest. Rr.

+ Dicranum japonicum Mitt. - [320-1350 m] SA: on soil in Betula lanata crooked forest, Rhododendron aureum shrubs and Calamagrostis meadow. Rr. B: on soil, at the trunk bases and fallen logs in spruce, larch and small-leaved forests of different types, more commonly on south-facing slopes. Fr. New for Amur Province.

Dicranum majus Turner - [Abr 1987] [400-1320 m] SA: on soil in Pinus pumila and Salix divaricata thickets in the upper course of Verevochkin Klyuch. Un. B: on soil in spruce and larch forests, mossy rock fields. Rr.

Dicranum montanum Hedw. - [Abr 1987] [330-1350 m] SA: on soil in Pinus pumila thickets, on trunk bases of birch in crooked Betula lanata forest. Rr. B: on rotten wood, tree trunks, including burnt ones. Com.

+ Dicranum nipponense Besch. - [550-1376 m] SA: in Rhododendron aureum-juniper reed grass meadow in the upper reaches of the Motovaya River. Un. B: on soil in larch and small-leaved forests on southern macroslope near cordons "52nd" and "34th". Rr.

+ Dicranum pacificum Ignatova \& Fedosov - [1393 m] SA: on soil in dwarf shrub lichen tundra. Un.

Dicranum polysetum Sw. - [Abr 1987] [340-1349 m] SA: on soil in sparse Betula lanata woodlands, in Pinus pumila thickets. Rr. $\mathrm{B}$ : on soil and rotten wood in forests of various types. Fr.

+ Dicranum schljakovii Ignatova \& Tubanova - [400$1434 \mathrm{~m}] \mathrm{SA}$ : on soil and rocks in dwarf shrub, moss tundras, in elfinwood communities, sparse Betula lanata forests. Sp. B: on rock outcrops, rock fields and on peat in Sphagnum bog. Rr.

Dicranum scoparium Hedw. - [Abr 1987] [340-1350 m] B: on soil, fallen logs and tree trunks in forests of various types. Fr. Apparently less common in the study area than a related species $D$. japonicum. Unlike the latter, it is typical for taiga forests on north-facing slopes and moss-covered rock fields. Differences in ecology between these two species need further studies.
Dicranum spadiceum J.E. Zetterst. - [Abr 1987] [340$1390 \mathrm{~m}] \mathrm{SA}$ : on soil, rock outcrops and rock pillars in dwarf shrub mountain tundras, Pinus pumila thickets and subalpine meadows. Sp. B: on rocks on rock fields, in larch forests. Sp.

Dicranum undulatum Schrad. ex Brid. - [Abr 1987] [350-1220 m] B: on soil in forests of various types. Sp.

+ Didymodon ferrugineus (Schimp. ex Besch.) M.O. Hill - [330-420 m] B \& HB: on basic rock outcrops. Sp.

+ Didymodon hedysariformis Otnyukova - [320-410 m] B \& HB: on cliffs, rock outcrops, and tree trunks in larch, oak and Betula davurica forests. Sp. Known from Yakutia (Ivanova et al. 2005), Republic of Buryatia, Zabaikalsky Territory (Afonina et al. 2017), Altai Mts. (Ignatov \& Ignatova, unpubl.) and Kamchatka (Czernyadjeva 2012). New to Amur Province.

+ Didymodon icmadophilus (Schimp. ex Müll. Hal.) R.H. Zander - [420 m] HB: on cliff of metamorphosed limestone in Izvestkovyi Klyuch valley. Un.

+ Didymodon cf. validus Limpr. - [Abr 1987] [330$360 \mathrm{~m}]$ B \& HB: on cliffs (schists and gneiss rich in calcium) in Izvestkovyi Klyuch valley, on northern bank of Motovaya River bay, right slope of the Gilui River valley, below the mouth of the Shirokaya River. Rr. The taxonomy of this group remains dubious and records of $D$. rigidulus by Abramova et al. (1987) are referred to this name.

+ Didymodon zanderi Afonina \& Ignatova - [330-770 m] B: on cliffs, predominantly near streams, on soil on aufeis glade, on bark of Salix cardiophylla and poplar in valley forest. Sp. Often forms extensive pure patches or carpets. Known in Altai Mts., Baikal Lake area and Transbaikalia, Anabar Plateau, Primorsky Territory (Afonina \& Ignatova 2007a) and Kamchatka (Czernyadjeva 2012). New to Amur Province.

Distichium capillaceum (Hedw.) Bruch, Schimp. \& W. Gümbel - [Abr 1987] [330-700 m] B \& HB: in crevices and niches of cliffs, on fine soil at cliff bases, between rocks in rock fields. Fr.

+ Ditrichum heteromallum (Hedw.) E. Britton - [320 1376 m] SA: on bare soil in Rhododendron aureum-juniper reed grass meadow. Un. B: on silt deposit in degraded birch-larch forest on the bank of the water reservoir. Un.

+ Ditrichum cf. rhynchostegium Kindb. - [1340 m] SA: on reed grass meadow with scattered birches, on fine soil in chipmunk burrow destroyed by a bear. Un.

+ Ditrichum pusillum (Hedw.) Hampe - [320 m] B: in communities of temporal draw-down zone of the water reservoir and in degraded birch-larch forests on the banks of water reservoir. Rr.

Drepanocladus aduncus (Hedw.) Warnst. - [Abr 1987] $[320 \mathrm{~m}] \mathrm{B}$ : mire near the lake on the low terrace of Gilui River. Rr.

+ Drummondia sinensis Müll. Hal. - [320-380 m] HB: cliffs on the left slope of Motovaya River bay, on fallen logs in larch forest at the right slope of the Zimoveiskyi Klyuch valley. Rr.

Encalypta ciliata Hedw. - [Abr 1987] [320-700 m] B \& HB: on cliffs, between rocks on steep rocky slopes. Sp.

+ Encalypta pilifera Funck - [370 m] HB: on cliffs in Betula davurica forest on a steep slope at the left side of the Motovaya River valley in its lower course. Un.

+ Encalypta trachymitria Ripart - $[320 \mathrm{~m}]$ HB: on limestone at the mouth of Izvestkovyi Klyuch (Petelin 24.VII.1989, MHA). Un.

Entodon concinnus (De Not.) Paris - [Abr 1987] [320$360 \mathrm{~m}] \mathrm{B}$ \& HB: on cliffs rich in calcium in Gilui Bay and in Izvestkovyi Klyuch bay. Rr.

+ Entodon giraldii Müll. Hal. - [420 m] HB: on limestone cliffs on a south-facing slope at the right slope of Izvestkovyi Bay. Un. 
Entodon schleicheri (Bruch, Schimp. \& W. Gümbel) Demet. - [Abr 1987] [600 m] B: on steep south-facing rocky slope of Bol'shaya Erakingra River valley. Un.

Entosthodon pulchellus (H. Philib.) Brugués - [350$630 \mathrm{~m}] \mathrm{B}$ \& $\mathrm{HB}$ : on cliffs rich in calcium compounds in Gilui River valley. Rr.

Eurhynchiadelphus eustegia (Besch.) Ignatov \& Huttunen - $[330 \mathrm{~m}] \mathrm{HB}$ : on limestone cliffs on south-facing slope on the right slope of Izvestkovyi Bay. Un. This species was also reported by Gambaryan (1977).

Eurhynchiastrum pulchellum (Hedw.) Ignatov \& Huttunen - [Abr 1987] [330-1350 m] SA: on rock in sparse Pinus pumila thicket. Un. B: on soil, rocks, rotten wood, tree trunk bases in forests and rock fields. Com.

+ Eurobypnum leptothallum (Müll. Hal.) Ando - [320$630 \mathrm{~m}]$ B \& HB: on cliffs, rocks on steep slopes. Rr.

+ Fabronia ciliaris (Brid.) Brid. - [320-700 m] B \& HB: on vertical cliff walls, in valleys of Zeya and Gilui Rivers. Sp.

+ Fabronia rostrata Broth. - [420-630 m] HB: on linden bark on steep southern slope in Izvestkovyi Bay, on cliffs on steep slope towards Zeya Reservoir at the mouth of Gilui Bay. Rr.

Fissidens bryoides Hedw. - [Abr 1987] [320-630 m] B \& HB: on cliffs, rocks, rock outcrops, fallen logs and trunk bases of Betula davurica. Sp.

- Fontinalis dalecarlica Bruch, Schimp. \& W. Gümbel - [Gambaryan 1978a] [Abr 1987] B: on rocks in rapidly flowing water of streams. Sp.

Funaria hygrometrica Hedw. - [Abr 1987] [320-650 m] B: on soil and upturned roots of fallen trees in valley forests, in burnt forest areas. Rr.

+ Glyphomitrium cf. humillimum (Mitt.) Cardot [350 m] B: on vertical walls in "Chertova Pechka" cliffs near the cordon "Izubriny". Un.

Grimmia elatior Bruch ex Bals.-Criv. \& De Not. [Gambaryan 1978b] [Abr 1987]: B: on rocks. Sp. There is a specimen in MHA collected by Gambaryan from Zhurban (at Zeya River bank, now drowned by the reservoir).

Grimmia jacutica Ignatova, Bednarek-Ochyra, Afonina \& J. Muñoz - [gnatova et al., 2003] [320-1355 m] SA: on rock outcrops and rock pillars in elfinwood thickets. Sp. B: on rocks in rock fields. Sp.

Grimmia longirostris Hook. - [Abr 1987] [320-1355 m] SA: on rocks, rock outcrops, rock pillars within elfinwood thickets. Fr. B \& HB: on rocks in forests, in cliffs of various composition. Com.

Grimmia pilifera P. Beauv. - [Abr 1987] [320-700 m] B \& HB: on cliffs and rock outcrops. Fr. Often abundant.

+ Gymnostomum aeruginosum Sm. - [320-420 m] B \& HB: on cliffs rich in calcium in Zeya and Gilui River valleys. Sp. Forms thick tufts.

+ Haplocladium angustifloium (Hampe \& Müll. Hal.) Broth. - [Abr 1987] [320-820 m] B \& HB: on trunk bases, fallen logs, rocks, rock outcrops in forests, predominantly on south-facing slopes. Fr.

+ Hedwigia emodica Hampe ex Müll. Hal. - [320$1350 \mathrm{~m}]$ B: on rock outcrops, rocks, bare soil, trunk bases in forests, predominantly on south-facing slopes. Fr.

+ Hedwigia kuzenevae Ignatova \& Ignatov - [350-579 m] Ecological preferences apparently similar to the previous species.

Helodium blandowii (F. Weber \& D. Mohr) Warnst. [Abr 1987] [340-700 m] B: on soil in floodplain larch and spruce forests, in larch forest on a north-facing slope. Rr. Small turfs among Sphagnum girgensobnii, Pleuroqium schreberi, Hylocomium splendens and other species.
- Helodium paludosum (Austin) Austin ex Broth. - [Abr 1987] B: in open larch stand, on soil. Rr. Gambaryan (1978b) reported this species from Boyarkinsky Klyuch and from Zhurban settlement (at Zeya River bank, now drowned by the reservoir).

Herpetineuron toccoae (Sull. \& Lesq.) Cardot - [Abr 1987] [320-330 m] B \& HB: on rock outcrops, rocks, "Chertova Pechka" cliffs; on steep cliffy left bank of Gilui Bay opposite Motovaya River Bay; in Teplyi Klyuch valley (Abramova et al. 1987). Rr.

Herzogiella turphacea (Lindb.) Z. Iwats. - [Abr 1987] [320-700 m] B: on rotten wood and trunk bases in wet forests. Rr.

+ Heterophyllium affine (Hook.) M. Fleisch. - [430$1260 \mathrm{~m}] \mathrm{B}$ : on fallen logs, spruce trunk bases in spruce and spruce-larch green moss forests. Rr.

Homalia trichomanoides (Hedw.) Bruch, Schimp. \& W. Gümbel - [Abr 1987] [320-450 m] B \& HB: in shaded niches and crevices of cliffs, under rocks in rock fields. Sp.

+ Homomallium connexum (Cardot) Broth. - [320 $400 \mathrm{~m}] \mathrm{B} \& \mathrm{HB}$ : on rock outcrops and boulders. Rr.

Homomallium incurvatum (Schrad. ex Brid.) Loeske [Abr 1987] [320-860 m] B \& HB: on rock outcrops, boulders, trunk bases of trees in forests on south-facing slopes. Rr.

+ Hondaella caperata (Mitt.) Ando, B.C. Tan \& Z. Iwats. - $[330 \mathrm{~m}] \mathrm{HB}$ : on shaded limestone outcrops in Izvestkovyi Klyuch valley. Un. This species is known in Russia from only a few localities in southern Russian Far East, in Bastak Nature Reserve in Jewish Autonomous Region, in Bolshekhekhtsirsky Nature Reserve in Khabarovsk Territory, at Zmeinava River (tributary of Bikin River), and in Kedrovaya Pad Nature Reserve in Primorsky Territory. New to Amur Province. Included in the Red Data Book of Russian Federation (Cherdantseva 2008), category 2.

+ Hydrogonium amplexifolium (Mitt.) P.C. Chen [326-649 m] B \& HB: on basic rock outcrops (Izvestkovyi Klyuch; cliffs on the left slope of the Gilui River valley upstream Zolotoy Klyuch), on rocks in the valley of a stream - right tributary of Bol'shaya Erakingra River. Rr. In Russia, this species is known from scattered localities in Stanovoy Upland in Transbaikalia (Afonina et al. 2017), Eastern Yakutia (Ivanova et al. 2005), south-eastern part of Taimyrsky Region (Fedosov \& Zolotov 2008) and Altai Mts. (Ignatov \& Zander 1993). New to Amur Province.

Hygrohypnella ochracea (Turner ex Wilson) Ignatov \& Ignatova - [Abr 1987] [320-1300 m] SA: on rocks in water at the mouth of Verevochkin Klyuch. Un. B: on river banks and rocks in river and brook beds. Rr.

Hygrohypnella polaris (Lindb.) Ignatov \& Ignatova [Abr 1987] [320-770 m] B: on banks of rivers and brooks, on rocks in river beds. Rr.

+ Hygrohypnum luridum (Hedw.) Jenn. - [650 m] B: on rocks in a brook in the uppermost course of Shaman River. Un.

Hylocomium splendens (Hedw.) Bruch, Schimp. \& W.Gümbel - [Abr 1987] [320-1350 m] SA: on soil in Pinus pumila thickets. Rr. B: on soil, tree trunks and fallen logs in forests. More frequent on shaded slopes and in valleys. This species forms extensive moss cover in taiga forests. Com.

+ Hymenostylium recurvirostrum (Hedw.) Dixon [330-350 m] B \& HB: on cliffs rich in calcium (left and right slopes of the Gilui River vallev, below the mouth of the Shirokaya River, in Izvestkovyi Klyuch valley). Rr. New for Amur Province.

+ Hyophila involuta (Hook.) A. Jaeger - [330 m] HB: on shaded limestone outcrops in the Izvestkovyi Klyuch valley. Un. In Russia, known from Southern Primorye (Bardunov 2008) and several localities in South-Eastern Zabaikalsky Territory (Afonina et al. 2017). New to Amur Province. Included in the Red Data Book of Russian Federation (Bardunov 2008), category 3. 
Hypnum cupressiforme Hedw. - [Abr 1987] [320-1350 m] SA: on rock pillars, rocks in Pinus pumila thickets, on trunk bases of Betula lanata. Sp. B: on soil, trunk bases of trees in forests of various types. Sp. One specimen collected from the base of Larix gmelinii trunk near the cordon "20th km" was determined as Hypnum cupressiforme var. subjulaceum Molendo.

Hypnum saitoi Ando - [Abr 1987] [ $\approx 1200 \mathrm{~m}]$ B: on soil and rocks in subalpine spruce forest (Gambaryan 6.VII.1974, MW). Un. Reported by Gambaryan (1978a) as Rr.

+ Isopterygiopsis alpicola (Lindb. \& Arnell) Hedenäs [380-670 m] B \& HB: in crevices and niches of cliffs of various composition, on rocks with fine soil sediments. Sp. Together with Poblia cruda, Fissidens bryoides, Oxystegus tenuirostris.

+ Isopterygiopsis muelleriana (Schimp.) Z. Iwats. [340-1355 m] SA: on outcrops and soil between rocks in mountain tundra and in Pinus pumila thickets. Rr. B \& HB: on cliffs, on rocks on forested screes. Rr.

Isopterygiopsis pulchella (Hedw.) Z. Iwats. - [Abr 1987] [330-370 m] B \& HB: on rocks and tree trunk bases. Rr.

Iwatsukiella leucotricha (Mitt.) W.R. Buck \& H.A. Crum - [Abr 1987] [330-1350 m] SA: on trunk of Pinus pumila. Rr. B: on bark of tree branches and trunks, more frequently on spruce. Sp.

Leptobryum pyriforme (Hedw.) Wilson - [Abr 1987] [390-410 m] B: on cliffs, silt deposit near brooks and in the temporarily exposed draw-down zone of the water reservoir. Rr.

+ Leptodontium flexifolium (Dicks.) Hampe - [330 $630 \mathrm{~m}]$ B \& HB: on bark of Betula davurica and aspen, on fallen logs. Rr.

+ Leucodon coreensis Cardot - [360 m] B: on a cliff on the right slope of the Gilui River valley, below the mouth of the Shirokaya River. Un.

Leucodon pendulus Lindb. - [Abr 1987] [330-1265 m] B: on branches and trunks of spruce, poplar and birch trees in valley forests, in subalpine spruce forests. Sp.

Leucodon sciuroides (Hedw.) Schwägr. - [Abr 1987] $[330-380 \mathrm{~m}] \mathrm{B}$ : on trunks of spruce and birch trees in valleys. Rr.

+ Lewinskya cf. affinis (Brid.) F. Lara, Garilleti \& Goffinet (=Ortotrichum affine Brid.) - $[660 \mathrm{~m}] \mathrm{B}$ : on trunk of a willow tree in Bol'shaya Erakingra River valley. Rr. Newly recorded for Amur Province; however, further studies are needed for clarifying taxonomy in this group.

+ Lewinskya elegans (Schwägr. ex Hook. \& Grev.) F. Lara, Garilleti \& Goffinet (=Orthotrichum elegans Schwäfgr. ex Hook. \& Grev.) - [Abr 1987] [340-850 m] B: on bark of aspen, birch, poplar and willows in forests of various types. Sp. Previously not listed for the region; however, the recent revision of the family Orthotrichaceae in Russia (Fedosov \& Doroshina 2018) demonstrated that all specimens from the Zeysky Nature Reserve identified as Orthotrichum speciosum Nees actually belong to L. elegans.

+ Lewinskya iwatsukii (Ignatov) F. Lara, Garilleti \& Goffinet (= Orthotrichum iwatsukii Ignatov) - [360-820 m] $\mathrm{B}$ : on branches and trunks of aspen, birch and spruce in forests of various types. Sp.

Lewinskya sordida (Sull. \& Lesq.) F. Lara, Garilleti \& Goffinet (=Orthotrichum sordidum Sull. \& Lesq.) - [Abr 1987] [320-1280 m] SA: on bark of Betula lanata in sparse birch woodland. Rr. B \& HB: on trunks and branches of birch, willows, aspen, spruce, and oak trees in forests of various types. Fr.

+ Lewinskya transcaucasica Eckstein, Garilleti \& F. Lara $-[380-1282 \mathrm{~m}]$ B: on bark of birch, aspen and willow in valley and slope forests. Rr. This species has been recently discovered in Russia (Fedosov et al. 2017) and is comparatively common in southern Russian Far East. All specimens from Zeysky Nature Reserve previously identified as Orthotrichum striatum Hedw. actually belong to L. transcaucasica.
Mnium lycopodioides Schwägr. - [Abr 1987] [320-650 m] $\mathrm{B} \& \mathrm{HB}$ : in crevices, shaded niches of cliffs, between rocks of rock fields. Rr.

Mnium marginatum (Dicks.) P. Beauv - [Abr 1987] [320-350 m] B: in spruce forest in Kamrai Klyuch (Petelin 5.IX.1979, MW), on birch hanging over water in the Teplyi Klyuch valley (L.I. Abramova 16.VIII.1980, MW). Rr. These localities were likely flooded by Zeya Reservoir.

Mnium spinulosum Bruch, Schimp. \& W. Gümbel [Abr 1987] [640-1310 m] B: on soil, fallen logs, mounds at the trunks of trees in spruce forests. Sp.

Mnium thomsonii Schimp. - [Abr 1987] [320-600 m] B \& HB: in crevices, shaded niches of cliffs, on trunk bases of trees, fallen logs and rocks in valley forests. Sp.

+ Molendoa sendtneriana (Bruch, Schimp. \& W. Gümbel) Limpr. - [320-420 m] B \& HB: on base-rich cliffs in Zeya and Gilui River valleys. Sp. Generally in pure mats.

Myurella julacea (Schwägr.) Bruch, Schimp. \& W. Gümbel - [Abr 1987] [330-650 m] B: on vertical walls of bare soil, rocks, fallen logs, trunk bases of trees in valley forests, in crevices of cliffs. Sp.

+ Myurella sibirica (Müll. Hal.) Reimers - [330-360 m] B \& HB: on wet calcareous cliffs in Zeya and Gilui River valleys. Rr. Often with Abietinella abietina, Bryoerythrophyllum recurvirostrum, Distichium capillaceum, Brachythecium daburicum. New for Amur Province.

+ Myuroclada longiramea (Müll. Hal.) Min Li, Y.F. Wang, Ignatov \& Huttunen - [320-570 m] B: on soil in valley forests, communities in the temporarily exposed draw-down zone of the water reservoir. Rr.

Myuroclada maximowiczii (G.G. Borshch.) Steere \& W.B. Schofield - [Abr 1987] [320-410 m] B: on fine soil in shaded niches of cliffs, on soil, trunk bases of trees in valley forests. Sp. HB: on cliffs, soil, trunk bases of Quercus mongolica in forests on exposed slopes. Sp.

Neckera pennata Hedw. - [Abr 1987] [330-1150 m] B: on trunks of spruce and poplar, on fallen logs in spruce forests; between rocks on forested block screes, in crevices and niches of cliffs. Sp.

Niphotrichum canescens (Hedw.) Bedn.-Ochyra \& Ochyra - [Abr 1987] [350-1380 m] SA: on soil and rocks in mountain tundras. Rr. B: on alluvium in river valleys, on rocks of rock fields. Rr.

+ Niphotrichum panschii (Müll. Hal.) Bedn.-Ochyra \& Ochyra - [320-350 m] B: on rocks of rock fields, on gravel and sandy alluvium in valleys of rivers. Sp.

Nybolmiella obtusifolia (Brid.) Holmen \& E. Warncke (=Ortotrichum obtusifolium Brid.) - [Abr 1987] [320-820 m] B \& HB: on bark of deciduous trees. Sp.

+ Oncophorus elongatus (I. Hagen) Hedenäs - [320-420 m] $\mathrm{B}$ : on fallen logs in birch-larch forests. Rr. This species was recently re-instated (Hedenäs 2017). Its ecological preferences and frequency of occurrence in the territory need further studies.

Oncophorus virens (Hedw.) Brid. - [Abr 1987] [320$700 \mathrm{~m}] \mathrm{B}$ : on gravel and sandy alluvium, cliffs and rocks near watercourses, on soil in valley forests and on aufeis glades. Sp.

Oncophorus wablenbergii Brid. - [Abr 1987] [330-1350 m] B: on fallen logs, tree stumps and trunk bases in forests. Fr. Herbarium specimens previously identified as $O$. wablenbergii need to be revised as some of them may belong to $O$. elongatus.

+ Oxystegus tenuirostris (Hook. \& Taylor) A.J.E. Sm. [320-820 m] B \& HB: in cliff crevices, on fallen logs, bark of spruce, aspen, Quercus mongolica and Betula davurica. Sp. Often with Haplocladium angustifolium, Poblia cruda, Isopterygiopsis alpicola.

Paludella squarrosa (Hedw.) Brid. - [350-670 m] B: on wet soil in valley forests (sphagnous larch forests, poplar forests), on gravel near watercourses. Rr. 
+ Paraleucobryum longifolium (Hedw.) Loeske [1380-1400 m] SA: on soil in willow-Rhododendron tundra and Rhododendron aureum-juniper reed grass meadow. $\mathrm{Rr}$.

+ Philonotis cf. capillaris Lindb. - [320-490 m] B: on fine soil alluvium. Rr. Possibly widespread on alluvium along rivers and brooks, but easily overlooked and lacking in collections.

+ Philonotis fontana (Hedw.) Brid. - [350-700 m] B: on gravel, rocks in slow watercourses in floodplains of rivers. Sp.

+ Philonotis tomentella Molendo - [500 m] B: on gravel in reed grass-variegated horsetail willow forest in valley of the Garmakan River. Rr.

+ Plagiomnium acutum (Lindb.) T.J. Kop. - [400 m] HB: on soil in willow-alder community of floodplain of Izvestkovyi Klyuch. Un.

Plagiomnium confertidens (Lindb. \& Arnell) T.J. Kop. - [Abr 1987] [330-700 m] B: on bases of tree trunks, fallen logs in valley forests, predominantly in spruce forests, on cliffs. Rr. HB: on wet cliffs. Sp.

Plagiomnium cuspidatum (Hedw.) T.J. Kop. - [Abr 1987] [320-770 m] B: on soil, fallen logs, trunk bases of trees in forests, more often in valley forests; on fine soil in niches on rock outcrops. Com.

+ Plagiomnium drummondii (Bruch \& Schimp.) T.J. Kop. $-[640 \mathrm{~m}] \mathrm{B}$ : on soil in aspen forest on the right slope of Malaya Erakingra River valley. Un.

Plagiomnium ellipticum (Brid.) T.J. Kop. - [Abr 1987] [320-550 m] B: on soil, trunk bases, fallen logs in valley forests; in mires. Sp.

Plagiomnium rostratum (Schrad.) T.J. Kop. - [Abr 1987] $[317 \mathrm{~m}] \mathrm{B}$ : on soil of reed grass meadow in the temporarily exposed draw-down zone of the water reservoir; in birch forests (Abramova et al. 1987). Rr.

+ Plagiopus oederianus (Sw.) H.A. Crum \& L.E. Anderson - $330 \mathrm{~m}$ ] HB: on shaded limestone outcrops in the Izvestkovyi Klyuch. Un. Together with Distichium capillaceum, Myurella sibirica, Campyliadelphus chrysophyllus, Mnium thomsonii, Didymodon ferrugineus.

+ Plagiothecium cavifolium (Brid.) Z. Iwats. - [320$130 \mathrm{~m}$ ] B: on shaded wet cliffs, on soil near streams, on mounds at the trunk bases in subalpine spruce forest. Rr.

- Plagiothecium curvifolium Schlieph. ex Limpr. - [Abr 1987] HB: Teplyi Klyuch, on rotten log. Un.

Plagiothecium denticulatum (Hedw.) Bruch, Schimp. \& W. Gümbel - [Abr 1987] [360-1320 m] B: on fine soil along brooks, on rocks and fallen logs in spruce and larch forests. Rr.

Plagiothecium laetum Bruch, Schimp. \& W. Gümbel [Abr 1987] [320-1270 m] B: on soil, on fallen logs in wet forests, between rocks of rock fields. Rr.

- Plagiothecium latebricola Bruch, Schimp. \& W. Gümbel - [Abr 1987] B: near the mouth of Pryamoi Klyuch. Un.

- Plagiothecium nemorale (Mitt.) A. Jaeger - [Abr 1987] HB: Teplyi Klyuch, on rotten log. Un.

Platydictya jungermannioides (Brid.) H.A. Crum - [Abr 1987] [350 m] B: on a cliff on the left bank of Gilui River opposite Zolotoy Klyuch. Un. Also reported by Abramova et al. (1987) as Rr.

Platygyrium repens (Brid.) Bruch, Schimp. \& W. Gümbel - [Abr 1987] [320-800 m] B \& HB: on bark of birch, aspen, spruce and larch, on rocks, on fallen logs in forests of various types. Fr.

Pleurozium schreberi (Brid.) Mitt. - [Abr 1987] [320$1440 \mathrm{~m}] \mathrm{SA}$ : on soil in elfinwoods and dwarf shrub thickets in tundras, in Pinus pumila and crooked birch communities. Fr. B: on soil, rarer on fallen logs, trunk bases, rocks in coniferous and small-leaved forests. Com.
Podperaea krylovii (Podp.) Z. Iwats. \& Glime - [Abr 1987] [320-370 m] HB: on cliffs, rocks, trunk base of an oak. Rr. Grows with Weissia brachycarpa and Fissidens bryoides.

+ Pogonatum dentatum (Brid.) Brid. - [350-650 m] B: on barren soil, cliffs covered by fine soils in river floodplains and on tree roots in larch forest. Sp.

Pogonatum urnigerum (Hedw.) P. Beauv. - [Abr 1987] [330 $1300 \mathrm{~m}] \mathrm{B}$ : on fine soil on cliffs, weakly turfed areas on river and brook banks, and on upturned roots of fallen trees. Sp.

+ Pohlia andalusica (Höhn.) Broth. - [320-360 m] B: on silt deposit of a temporary brook in floodplain of the Gilui River and in the temporarily exposed draw-down zone of the water reservoir. Rr. Grows with Poblia andrewsii, Philonotis capillaris, Trichodon cylindricus.

+ Poblia andrewsii A.J. Shaw - [320-1300 m] B: on silt deposit in degraded birch-larch forest in the temporarily exposed draw-down zone of the water reservoir; on soil in valley poplar forest; on soil along brooks, on upturned roots of fallen spruce trees. Rr. This species is absent from the list of mosses of Zeya Reserve (Abramova et al. 1987); however, several specimens collected in subalpine spruce forest near the peak with $1442 \mathrm{~m}$ height mark by D.A. Petelin and L.I. Abramova in 1979-1980 are stored in MW.

+ Poblia annotina (Hedw.) Lindb. - [320 m] B: on soil in narrow valley with a permanent brook near cordon "Izubriny". Un.

+ Poblia bulbifera (Warnst.) Warnst. - [320-340 m] B: on silt deposit of a temporary brook in floodplain of the Gilui River and in the temporarily exposed draw-down zone of the water reservoir. Rr. Together with Ceratodon purpureus, Trichodon cylindricus, Calliergonella lindbergii, Poblia bulbifera, P. andrewsii.

Poblia cruda (Hedw.) Lindb. - [Abr 1987] [340-1390 m] SA: on fine soil in willow-Rhododendron tundras. Un. B: on cliffs, walls composed of fine soil, upturned roots of fallen trees, soil under roots and between rocks in forests. Sp. HB: in shaded wet niches of rock outcrops. Sp.

Poblia elongata Hedw. - [Abr 1987] [390-1310 m] SA: in crevices of rock outcrops in the upper course of Verevochkin Klyuch. Un. B: in crevices on cliffs, rarer on fallen logs in forests. Rr. Poblia elongata var. greenii (Brid.) A.J. Shaw was collected on cliffs on the right slope of Razvedochny Klyuch valley (tributary of Gilui River).

+ Poblia filum (Schimp.) Mårtensson - [320-360 m] B: on sandy alluvium in the low floodplain of the Gilui River, on silt deposit in the temporarily exposed draw-down zone of the water reservoir. Rr.

+ Poblia lescuriana (Sull.) Ochi - [1380 m] SA: on soil within grass-reed grass meadow on the main watershed of the ridge in the upper reaches of the Motovaya River. Un.

+ Poblia longicollis (Hedw.) Lindb. - [340-1390 m] SA: in crevices of granite buttes, on soil in willow-Rhododendron tundra. $\mathrm{Rr}$. B: on rock outcrops, rocky soil on steep slopes. Rr.

Poblia nutans (Hedw.) Lindb. - [Abr 1987] [340-1380 m] SA: on soil in grass-reed grass meadow, on fine soil in chipmunk burrow destroyed by a bear, on trunk bases of birch within sparse birch forest. Sp. B: on fallen logs, trunk bases, soil and rocks in forests. Fr.

+ Poblia proligera (Kindb.) Lindb. ex Broth. - [320 m] B: on silt deposit in birch-larch forest in the temporarily exposed draw-down zone of the water reservoir. Un.

+ Poblia tundrae A.J. Shaw - [360 m] B: between rock blocks in fire-disturbed birch-larch forest on northern slope of the Tabuneika River valley, together with Eurbynchiastrum pulchellum, Trichodon cylindricus, Poblia cruda. Un. New to Amur Province.

Polytrichastrum alpinum (Hedw.) G.L. Sm. - [Abr 1987] [350-1400 m] SA: on soil, rocks covered by fine soil in tundras and elfinwood communities. Sp. B: on bare soil, fallen logs and rock outcrops in forests. Sp. 
Polytrichum commune Hedw. - [Abr 1987] [320-1370 m] SA: on soil in tundras, in communities of elfinwood, birch krummholtz. Fr. B: on soil, fallen logs, trunk bases of trees in forests. Com.

+ Polytrichum hyperboreum R. Br. - [610 m] B: On soil in poplar-alder forest in floodplain of Bol'shaya Erakingra Creek. Un.

Polytrichum jensenii I. Hagen - [Abr 1987] [380 m] SA: Gambaryan (1978b) reported one collection from mountain tundra. B: on a mire near a lake on the watershed of Shirokaya and Zolotaya Rivers (Petelin 11.IX.1979, MW). Un.

Polytrichum juniperinum Hedw. - [Abr 1987] [320 $1440 \mathrm{~m}] \mathrm{SA}$ : on soil in mountain tundra, reed grass meadow. Rr. B: on soil, trunk bases of trees, fallen logs in forests and in bogs. Common in burnt forest areas. Fr.

Polytrichum longisetum Sw. ex Brid. - [Abr 1987] [360 $1300 \mathrm{~m}] \mathrm{B}$ : on upturned roots of fallen trees in subalpine spruce forest near $1442 \mathrm{~m}$ peak, on soil and on trunk of fallen larch near lake on the watershed of Shirokaya and Zolotaya Rivers, on alluvium in low floodplain of the Gilui River. Rr.

- Polytrichum pallidisetum Funck (P. obioense auct.) [Gambaryan 1978a] [Abr 1987] SA: Pinus pumila thickets. Rr.

Polytrichum piliferum Hedw. - [Abr 1987] [320-1400 m] SA: on soil in dwarf shrub tundras, in elfinwood communities, reed grass meadows. Fr. B: on soil in open forests, in burnt forest areas; on bogs; on fine soil and screes. Sp.

Polytrichum strictum Brid. - [Abr 1987] [320-1400 m] SA: on soil in mountain tundras, predominantly of dwarf shrub-moss type, in elfinwood communities. Fr. B: on peat in mires. Sp.

+ Polytrichum swartzii Hartm. - [320-370 m] B: on peat in mires along Gilui River. Rr.

Pseudobryum cinclidioides (Huebener) T.J. Kop. - [Abr 1987] [350-670 m] B: on wet soil in valley forests, along oxbows, brook banks and mires. Sp.

+ Pseudoleskeella papillosa (Lindb.) Kindb. - [650 m] B: on rock on large-block rock field in the upper course of Motovaya River. Un.

+ Psilopilum cavifolium (Wilson) I. Hagen - [350 m] B: on rocky bank of the Gilui River opposite Chapovskaya sandspit (Barinov 15.IX.1991, MW and herbarium of Zeysky Reserve). Un. The nearest known localities of this species, which is rare in boreal regions, are from Stanovoe Upland (Zabaikalsky Territory) (Afonina et al. 2017). New for Amur Province and Southern Far East (Ivanova \& Ignatov 2017).

Ptilium crista-castrensis (Hedw.) De Not. - [Abr 1987] [330-1440 m] SA: on soil under tree trunks and between rocks, in elfinwoods and yerniks, in sparse birch forests. Sp. $\mathrm{B}$ : on soil, fallen logs, trunk bases of trees in forests, bogs and block screes. Com.

+ Ptychomitrium sinense (Mitt.) A. Jaeger - [320-340 m] HB: on exposed cliffs at the bank of Zeya Reservoir. Rr.

+ Pylaisia cf. curviramea Dixon - [420-580 m] B: on bark of aspen and birch in birch- and aspen-larch forests. Rr.

+ Pylaisia falcata Bruch, Schimp. \& W. Gümbel - [320 $820 \mathrm{~m}$ ] B \& HB: on bark of birch, aspen and poplar in forests of various types. Sp. In pure turfs or together with Callicladium baldanianum, Haplocladium angustifolium, Herzogiella turfacea, Homomallium connexum, Platygyrium repens, Pylaisiadelpha tenuirostris.

Pylaisia polyantha (Hedw.) Bruch, Schimp. \& W. Gümbel - [Abr 1987] [320-950 m] B \& HB: on bark of birch, aspen, spruce, poplar, Salix cardiophylla, on fallen logs in forests of various types. Sp. In pure turfs or mixed with Campylidium sommerfeltii, Dicranum flagellare, Haplocladium angustifolium, Oncophorus wablenbergii, Oxystegus tenuirostris, Platygyrium repens, Poblia nutans, Sanionia uncinata, Zygodon sibiricus.

+ Pylaisia selwynii Kindb. - [315-160 m] B \& HB: on bark of aspen, poplar and Betula davurica, on cliffs. Sp. Commonly in pure turfs.
+ Pylaisia steerei (Ando \& Higuchi) Ignatov - [370 $760 \mathrm{~m}]$ B \& HB: on fallen logs, rock and trunks of aspen in birch-larch and Betula davurica forests. Rr.

Pylaisiadelpha tenuirostris (Bruch \& Schimp. ex Sull.) W.R. Buck - [Abr 1987] [320-820 m] B: on bark of birch, aspen and larch, on fallen logs in birch- and aspen-larch forests. Fr. One of the most common epiphytic mosses. In pure turfs or together with Abietinella abietina, Brothera leana, Ceratodon purpureus, Dicranum montanum, Fissidens $\mathrm{cf}$. bryoides, Iwatsukiella leucotricha, Platygyrium repens, Poblia cruda, Pylaisia polyantha, Stereodon pallescens. Reported by Abramova et al. (1987) as Clastobryella kusatsuensis.

Rhabdoweisia crispata (Dicks. ex With.) Lindb. (=Rhabdoweisia kuzenevae Broth.) - [Abr 1987] [340-1220 m] SA: on soil in mountain tundra. (Abramova et al. 1987). B: in cliff niches and crevices, on rocks. Sp.

+ Rhodobryum ontariense (Kindb.) Kindb. - [330-370 m] $\mathrm{B}$ : on fallen logs, trunk bases of spruce and poplar, on soil in valley forests. Rr. Apparently, previous records of Rhodobryum roseum (Hedw.) Limpr. in Zeysky Nature Reserve (Abramova et al. 1987) should be referred to $R$. ontariense.

Rhytidiadelphus triquetrus (Hedw.) Warnst. - [Abr 1987] [320-1350 m] SA: on soil between rocks in elfinwood communities. Rr. B: on soil, tree trunk bases in valley forests and rocks near watercourses in narrow valleys. Sp.

Rhytidium rugosum (Hedw.) Kindb. - [Abr 1987] [320 $1440 \mathrm{~m}] \mathrm{SA}$ : on soils, on rocks in dwarf shrub tundras, often in abundance. Fr. B \& HB: on soil, among rocks, on tree trunk bases of trees in forests, commonly on southfacing slopes, rocky deposits, and cliffs. Com.

Saelania glaucescens (Hedw.) Broth. - [Abr 1987 [340-720 m] B: on upturned roots of fallen trees, bare soil between rocks, fallen logs and in shaded niches of cliffs. Sp.

Sanionia uncinata (Hedw.) Loeske - [Abr 1987] [320 $1380 \mathrm{~m}] \mathrm{SA}$ : on soil in elfinwood communities, reed grass meadows in areas with snow accumulation. Sp. B: on soil, fallen logs, trunk bases of trees and rocks in forests of various types. Com.

+ Schistidium austrosibiricum Ignatova \& H.H. Blom - [420-650 m] B: on rocks in rock fields. Rr.

+ Schistidium lancifolium (Kindb.) H.H. Blom - [320$520 \mathrm{~m}]$ B: on rock outcrops. Rr.

+ Schistidium liliputanum (Müll. Hal.) Deguchi - [340 $520 \mathrm{~m}$ ] B: on vertical surfaces of rock outcrops, on rocks in rock fields. Sp. New to Amur Province (Ignatova \& Blom 2017).

+ Schistidium marginale H.H. Blom, Bedn.-Ochyra \& Ochyra - $[370 \mathrm{~m}]$ HB: on rock outcrop on the left bank of Gilui Bay opposite Motovaya River mouth. Un. New to Amur Province (Ignatova \& Blom 2017).

+ Schistidium papillosum Culm. - [340-700 m] B \& HB: on rock outcrops and rocks in forests. Rr.

+ Schistidium platyphyllum (Mitt.) Perss. - [330 m] B: on rocks in floodplain of the Gilui River. Un.

+ Schistidium pulchrum H.H. Blom - [320-430 m] B \& HB: on vertical walls of rock outcrops, on rocks. Fr.

+ Schistidium sibiricum Ignatova \& H.H. Blom - [340 $770 \mathrm{~m}] \mathrm{B}$ : on rocks in valley forests, meadows in the low floodplain of the Gilui River, on cliffs near watercourses. Sp.

+ Schistidium subjulaceum H.H. Blom - [650 m] B: cliffs near water in the upper course of Motovaya River. Un. New to Amur Province (Ignatova \& Blom 2017).

Schistostega pennata (Hedw.) F. Weber \& D. Mohr - [Abr 1987] [440-1320 m] B: between rocks on forested screes, on upturned roots of fallen trees in spruce forests. Rr.

+ Sciuro-bypnum curtum (Lindb.) Ignatov - [430-1270 m] B: on soil, fallen logs in mossy spruce and larch-spruce forests. Sp. 
Sciuro-hypnum plumosum (Hedw.) Ignatov \& Huttunen - [Abr 1987] [330-860 m] B: on soil, rocks, on fallen logs in floodplain forests and meadows in low floodplain of the Gilui River. Sp.

Sciuro-bypnum cf. reflexum (Starke) Ignatov \& Huttunen - [Abr 1987] [1380 m] SA: on soil in Rhododendron aureumjuniper reed grass meadow in lately melted snowbed area. Un. Another locality at the mouth of Promyslowy Klyuch is reported by Abramova et al. (1987).

- Scorpidium revolvens (Sw. ex anon.) Rubers - [Abr 1987] SA \& B: mountain tundras and mires. Rr.

+ Scouleria pulcherrima Broth. [330 m] B: on boulders on the Gilui River floodplain (Barinov 20.VIII.1992, MW and Zeysky Reserve herbarium). Rr. Brotherus (1916) and Ignatova et al. (2015) include references to finding this species in many places along Gilyi and Zeva Rivers; one record was from Zeya River where it crosses the Tukuringra Range.

+ Seligeria donniana (Sm.) Müll. Hal. - [330 m] HB: in shaded crevice of limestone cliff in the Izvestkovyi Klyuch valley. Un.

+ Seligeria tristichoides Kindb. - [330 m] HB: in shaded crevice of limestone cliffs in the Izvestkovyi Klyuch valley. Un.

+ Sphagnum alaskense R.E. Andrus - [320 m] B: Sphagnum lindbergii bog with Carex limosa in waterlogged lowland on terrace of Gilui River, $1 \mathrm{~km}$ upstream from cordon "Izubriny". Un.

Sphagnum angustifolium (C.E.O. Jensen ex Russow) C.E.O. Jensen - [Abr 1987] [320-1420 m] SA: in mountain tundra. Rr. B: in boggy forests. Sp.

Sphagnum aongstroemii Hartm. - [Abr 1987] [350$1370 \mathrm{~m}]$ SA: at edges of hollows in mossy tundras and subalpine bogs. Sp. B: along the brook in subalpine spruce forest, in spruce forest in the Malyi Garmakan River valley, in boggy larch forest along the brook in the Beloborodovsky Klyuch valley. Rr.

Sphagnum balticum (Russow) C.E.O. Jensen - [Abr 1987] [340-1440 m] SA: in moss-lichen and mossy tundras. Sp. B: Sphagnum bogs, boggy larch forests. Sp. Often with Sphagnum lenense and S. divinum.

+ Sphagnum beringiense A.J. Shaw, R.E. Andrus \& B. Shaw - $[320 \mathrm{~m}] \mathrm{B}$ : in eutrophic lake on the terrace of the Gilui River near the mouth Zolotoy Klyuch; on boggy clearing for power transmission-line (Petelin 25.IX.1979, MW). Rr. With Sphagnum flexuosum.

+ Sphagnum capillifolium (Ehrh.) Hedw. - [320-870 m] B: in Sphagnum bogs and boggy larch forests. Rr.

- Sphagnum centrale C.E.O. Jensen - [Abr 1987] B: coniferous forests. Rr.

Sphagnum compactum Lam. \& DC. - [Gambaryan 1978a] [Abr 1987] [390-1440 m] SA: in lichen-moss tundras, along brooks and areas of solifluction disturbance in mossy tundras. Sp. B: single record in Sphagnum bog with scattered larch trees in the valley of the Nizhny Chimchan River. Un.

Sphagnum divinum Flatberg \& Hassel (S. magellanicum auct.) - [Abr 1987] [320-1400 m] SA: in mossy tundras. Fr. B: in boggy larch forests and Sphagnum bogs. Fr.

Sphagnum fallax (H. Klinggr.) H. Klinggr. - [Abr 1987$]$ [1342 m] SA: in hollow of cotton-grass lichen-moss bog in the watershed in the upper reaches of the Motovava River. Un. Abramova et al. (1987) reported it as sporadic in forests: Sp.

+ Sphagnum flexuosum Dozy \& Molk. - [320-380 m] B: in the Warnstorfia \& Sphagnum mire with sedges on the terrace of the Gilui River opposite Zolotoy Klyuch, on the bank of lake in the watershed of Shirokaya and Zolotaya Rivers. Rr.

Sphagnum fimbriatum C.E.O. Jensen - [Gambaryan 1978a [Abr 1987]: B: spruce forest. Rr. There is a specimen in MHA collected by Gambaryan from Zhurban (at Zeya
River bank, now drowned by the reservoir).

Sphagnum fuscum (Schimp.) H. Klinggr. - [Abr 1987] [370-1300 m] B: in boggy larch forests, in spruce forests. Sp. Abramova et al. (1987) considered it as a common species.

Sphagnum girgensohnii Russow - [Abr 1987] [330$1350 \mathrm{~m}] \mathrm{SA}$ : in elfinwood and dwarf birch communities. Rr. B: in bogs, spruce and larch forests. Com. One of the main dominant species of the moss layer.

+ Sphagnum imbricatum Hornsch. ex Russow s. str. [1340 m] SA: moss tundra in the lower part of eastern slope on the main watershed ridge in the upper reaches of the Motovaya River and Burlivy Klyuch Creek. Un.

+ Sphagnum jensenii H. Lindb. - [340-1370 m] SA: in small brook in mossy tundra on the main watershed of Tukuringra Ridge in the upper reaches of the Motovaya River and Burlivy Klyuch Creek. Un. B: hollows in mire on terrace of Gilui River. Rr.

Sphagnum lenense H. Lindb. ex L.I. Savicz - [Abr 1987] [330-1400 m] SA: in mossy mountain tundras. Fr. B: in boggy larch forests and Sphagnum bogs. Fr.

+ Sphagnum lindbergii Schimp. - [320 m] B: Sphagnum lindbergii bog with Carex limosa in waterlogged lowland on terrace of the Gilui River, $1 \mathrm{~km}$ upstream from cordon "Izubriny". Un.

+ Sphagnum mirum Flatberg \& Thingsgaard - [380 m] B: sedge-Sphagnum bog near the lake in the watershed between Shirokaya (Stepanak) River and Zolotoi Klyuch Creek. Un. In Russia, it is currently known from Kodar Mt. Range in the north of Zabaikalsky Territory, Taimyr and Chukotka (Flatberg et al. 2016). New to the southern Russian Far East and Amur Province.

Sphagnum obtusum Warnst. - [Abr 1987] [320-380 m] B: on mire on the Gilui terrace opposite of the Zolotoy spring, along the lake bank on the watershed of Shirokaya and Zolotaya Rivers. Rr.

- Sphagnum orientale L. Savicz - [Gambaryan 1978a] [Abr 1987] SA \& B: mountain tundra and forests. Rr. There are correctly identified specimens collected by Gambaryan in MHA, from areas neighbouring to reserve.

Sphagnum rubellum Wilson - [Abr 1987] [650-1000 ? m] B: mires and boggy spruce forests. Rr.

Sphagnum russowii Warnst. - [Abr 1987] [1320 m] B: in spruce mossy forest in the upper course of Valunnyi Klyuch. Un. Abramova et al. (1987) considered it as a sporadically occuring in the boreal belt as well.

Sphagnum squarrosum Crome - [Abr 1987] [380-1180 m] B: on wet banks of brooks, in hollows of lake floating mats, in boggy clearing for power transmission-line. Sp.

+ Sphagnum tenellum (Brid.) Pers. ex Brid. - [390 m] B: in Sphagnum bog on the terrace of the Nizhny Chimchan River. Un.

Sphagnum teres (Schimp.) Ångstr. - [Abr 1987] [380$1442 \mathrm{~m}]$ SA: several collections from mountain tundra. Rr. B: along temporary courses in river valleys, on aufeis glades, in mires and on soil in subalpine spruce forest. Sp.

+ Sphagnum tundrae Flatberg - [320-700 m] B: on alluvium along brooks, on soil in spruce, alder and poplar valley forests. Sp.

- Sphagnum wulfianum Girg. - [Abr 1987] B: in spruce forest in Bol'shaya Erakingra Creek valley. Un.

- Splachnum rubrum Hedw. - [Abr 1987] B: Motovaya River mouth, in forest. Un.

+ Stereodon calcicola (Ando) Afonina \& Cherd. - [330 m] $\mathrm{HB}$ : on horizontal ledges of limestone cliffs in the Izvestkovyi Klyuch valley. Un. An East-Asian species, known from Japan and two localities in Russia in Southern Primorye (Afonina \& Ignatova 2007 b), where it also occurs on limestone outcrops. 
New to Amur Province.

+ Stereodon fauriei (Cardot) Ignatov \& Ignatova - [350 $700 \mathrm{~m}]$ B: on fallen logs in larch and small-leaved forests. Rr.

Stereodon pallescens (Hedw.) Mitt. - [Abr 1987] [340$1200 \mathrm{~m}] \mathrm{B}$ : on fallen logs, rocks and trunk bases of trees in forests of various types. Fr. Often found with Stereodon plicatulus, Pylaisiadelpha tenuirostris, Sanionia uncinata.

+ Stereodon plicatulus Lindb. - [320-1400 m] SA: on soil in mountain tundras, on bark of Duscheckia fruticosa in elfinwood communities. Sp. B: on fallen logs, trunks of deciduous and coniferous trees. Fr.

+ Stereodon cf. subimponens (Lesq.) Broth. - [500 m] B: on carbonate outcrops on the right slope of the Gilui River valley, $3 \mathrm{~km}$ upstream from the mouth of Razvedochnyi Klyuch. Un.

+ Stereodon vaucheri (Lesq.) Lindb. ex Broth. - [630 m] B: on rock in aspen forest at the mouth of Gilui Bay. Un.

Straminergon stramineum (Dicks. ex Brid.) Hedenäs - [Abr 1987] [320-390 m] B: on soil on river and brook banks, in Sphagnum bogs. Sp.

+ Syntrichia pagorum (Milde) J.J. Amann - [320 m] HB: on schist outcrops at the shore of Zeya Reservoir between Razvedochny and Sukhoy Klyuch Creeks. Un. With Didymodon spp. and Ptychomitrium sinense.

+ Syntrichia sinensis (Müll. Hal.) Ochyra - [320-700 m] B \& HB: on rocks, rock outcrops on southern slopes and exposed cliff walls. Sp.

Tetraphis pellucida Hedw. - [Abr 1987] [330-1270 m] B: on rotten wood in forests of various types. Fr.

Tetraplodon angustatus (Hedw.) Bruch, Schimp. \& W. Gümbel - [Gambaryan 1977, 1978a] [Abr 1987] [350$1300 \mathrm{~m}$ ] SA: on cliffs in Pinus pumila thickets (Abramova et al. 1987). B: on soil at the mouth of Kamrai River and near the cordon "Ludoed"; on scree along the right slope of the Shirokaya River valley. Rr.

Tetraplodon mnioides (Hedw.) Bruch, Schimp. \& W. Gümbel - $[350 \mathrm{~m}]$ B: on soil near the cordon "Ludoed" (Barinov 10.IX.1991, MW and Zeysky Reserve herbarium). Un.

Thuidium assimile (Mitt.) A. Jaeger - [Abr 1987] [320 $700 \mathrm{~m}]$ B \& HB: on rocks, fallen logs, trunk bases of deciduous trees in forests of various types and calcareous cliffs. Fr.

Timmia bavarica Hessl. - [Abr 1987] [330 m] B \& HB: on horizontal ledges of limestone cliffs in the Izvestkovyi Klyuch valley. Rr.

+ Timmia comata Lindb. \& Arnell - [320-340 m] B \& HB: on calcareous rock outcrops in the Gilui River and Izvestkovyi Klyuch valleys. Rr. New for Amur Province (Ignatov \& Ignatova 2017).

+ Timmia megapolitana Hedw. - [330 m] B: on soil in floodplain forest at the mouth of Shirokaya River (Petelin 11.IX.1979, MW). Rr. New for Amur Province (Ignatov \& Ignatova 2017).

+ Timmiella anomala (Bruch \& Schimp.) Limpr. - [320 m] HB: on dry schist outcrops on the shore of Zeya Reservoir between Razvedochny and Sukhoy Klyuch Creeks. Un.

Tomentypnum nitens (Hedw.) Loeske - [Abr 1987] [320 $370 \mathrm{~m}$ ] B: in boggy sparse larch forests in river valleys. Rr. Abramova et al (1987) reported it as Fr.

Tortella fragilis (Hook. \& Wilson) Limpr. - [Abr 1987] [330-650 m] B: on cliffs, trunks of alder (Alnus hirsuta) trees and on soil in valley forests. Rr.

Tortella tortuosa (Hedw.) Limpr. - [Abr 1987] [340 m] B: on calcareous rock outcrops in the narrow valley of Gilui River. Rr.

Trachycystis ussuriensis (Maack \& Regel) T.J. Kop. [Abr 1987] [320-360 m] B \& HB: in crevices and shaded niches of calcareous rocks; on fallen logs in valley forests. Rr. + Trichodon cylindricus (Hedw.) Schimp. - [Abr 1987] [315-1320 m] B: in meadow communities in the drawdown zone of the water reservoir, on sandy alluvium on the bank of the Gilui River and of brooks with slow current, on upturned roots of fallen trees in forests. Rr.

Trichostomum crispulum Bruch - [Abr 1987] [340 m] B: on calcareous rock outcrops on the right slope of Gilui River valley, $3 \mathrm{~km}$ upstream from the mouth of Razvedochnyi Klyuch Creek. Un.

Ulota curvifolia (Wahlenb.) Sw. - [Abr 1987] [350 m] $\mathrm{B}$ : rock crevices in larch forest on north-western slope near the Tabuneika River backwater area (L.I. Abramova, 11.VIII.1980, MW). Un.

+ Ulota rehmannii Jur. - [330-1270 m] B: on trunks of mountain ash, birch, aspen and spruce in forests of various types. Fr. Often mixed with Lewinskya elegans, L. iwatsukii, L. sordida, and Iwatsukiella leucotricha.

+ Ulota reptans Mitt. - [500 m] B: on birch in birch-larch forest in vicinity of cordon " $20 \mathrm{th} \mathrm{km}$ ". Un.

Warnstorfia exannulata (Bruch, Schimp. \& W. Gümbel) Loeske - [Abr 1987] [320-1370 m] SA: in hollows in moss tundras. Sp. B: in temporary watercourses in floodplains of rivers, in small lakes on terrace of the Gilui River. Rr.

+ Warnstorfia fluitans (Hedw.) Loeske - [320-650 m] B: in bog near small overgrowing lake on left bank of Gilui Bay on the Zeya Reservoir opposite Zolotoy Klyuch mouth; in a depression in sparse larch forest with Alnus birsuta in the valley of Malaya Erakingra River. Rr.

Warnstorfia sarmentosa (Wahlenb.) Hedenäs - [Abr 1987] [640-660 m] B: on gravel and rocks in the valleys of Bol'shaya Erakingra River and Motovaya River. Rr.

+ Weissia brachycarpa (Nees \& Hornsch.) Jur. - [320$410 \mathrm{~m}] \mathrm{B} \& \mathrm{HB}$ : in cliff crevices and niches. Sp.

Zygodon sibiricus Ignatov, Ignatova, Z. Iwats. \& B.C. Tan (cited by Abramova et al. 1987 as Z. conoidens) - [Abr 1987] [330-800 m] B: on trunks of poplar, willow and aspen in forests, more often in valley forests. Sp.

\section{Species excluded}

Three groups of species previously reported from Zeysky Reserve are not included in the present check-list for the following reasons:

1. Some moss genera were revised, resulting in considerably narrower species concepts, which made it impossible to interpret unconfirmed literature data. For this reason, the records of Hedwigia ciliata, Racomitrium heterostichum, Schistidium alpicola, S. apocarpum, S. strictum, and Ulota crispa have been excluded and, moreover, they cannot be attributed to any single accepted species, but only to the species group. All available specimens of these genera were re-identified and included in the present paper, but without correspondence with any names used before. It is important to distinguish these cases from those when, despite the species splitting, all plants from the study area can be named with certainty. For example, all plants formerly referred to as $S$. magellanicum are now classified as $S$. divinum, or all Zygodon records in Siberia now are considered as $Z$. sibiricus (previously called as $Z$. conoideus, $Z$. rupestris, or $Z$. viridissimus). In such cases we indicate changes in text without listing them among the species excluded.

2. A number of species reported by Abramova et al. (1987) but not confirmed by herbarium specimens, are referred to as doubtful for at least one of the following rea- 
sons: (a) recent changes in taxonomy make the record highly unlikely; (b) species range has been re-appraised and there are no records currently known from any neighbouring areas; (c) species ecology as described by Abramova et al. (1987) raises doubts as to the veracity of the identification; (d) species localities proved to be outside the reserve area. These species are: Brybnia novae-angliae, Brachythecium glareosum, Bryum lonchocaulon, Cirriphyllum piliferum, Cnestrum glaucescens, Cynodontium polycarpon, Dicranum angustum, D. fulvum, D. mueblenbeckii, Didymodon rigidulus, Distichium inclinatum, Drepanocladus polygamus, D. sendtneri, Grimmia ovalis, G. elongata, Hymenoloma crispulum, Leptodictyum riparium, Meesia triquetra, Oxyrrbynchium hians, O. schleicheri, Palustriella commutata, Paraleucobryum enerve, Pseudoleskeella tectorum, Serpoleskea subtilis, Stereodon callichrous, Sphagnum warnstorfii and Thuidium delicatulum.

3. The catalogue of mosses of Russian reserves (Ignatov et al. 2004) lists a number of species for the Zeya Reserve that are absent in Abramova et al. (1987), without citing additional sources of information. Therefore, reports of the following species are considered to be technical errors: Bryum caespiticium, B. pallens, Codriophorus acicularis, Fontinalis antipyretica, Hygroamblystegium tenax, Plagiomnium japonicum and Rhizomnium punctatum. Species found in the course of present study which were listed by Ignatov et al. (2004) but not listed by Abramova et al. (1987) are considered here as new for the reserve (given with + in the list).

\section{FLORA ANALYSIS}

\section{Taxonomic diversity}

The moss flora of Zeysky Reserve currently includes 310 species (including 13 previously recorded species not supported by herbarium specimens) of 138 genera and 55 families. As many as 140 species are newly recorded for the reserve, and 25 species are also new for Amur Province. Thus, Zeysky Reserve has the most diverse moss flora of all the Nature Reserves of Transbaikalia and continental southern Russian Far East (Table 2).

In Zeysky Reserve, the family Sphagnaceae is the largest one, with 28 species. This is is explained by the great diversity of both eutrophic and oligotrophic waterlogged habitats. The second richest family is the Pottiaceae, with 22 species, which reflects the abundance of calcareous and base-rich substrates. Then follow the Dicranaceae, in the narrow sense, which includes 21 species, and the Grimmiaceae, with 30 species, which reflect mountain specificity of the flora. Fifth and sixth are the Pylaisiaceae and
Brachytheciaceae, with 17 and 16 species respectively, mainly epiphytic and epixylic mosses. The ratio Pottiaceae / Dicranaceae s.l. in the flora of Zeysky Reserve is lower than 1 (0.71), which is typical for moss floras of humid areas (Ignatov 2001).

Among genera, the first three places in the flora are occupied by Sphagnum, with 28 species, Dicranum with 20, and Poblia with 12. This ratio is typical for humid boreal mountain bryofloras; this has been shown for Bureinsky, Norsky and Botchinsky Reserves, as well as for the Udokan Ridge. The genus Schistidium is rather diverse in Zeysky Reserve, including 9 species. Among the other comparable floras, only Sokhondinsky Reserve has a richer number of species for this genus (with 10 species).

\section{Altitudinal distribution of mosses}

Distribution of mosses in six altitudinal intervals, based on herbarium specimens and vegetation relevés, is shown in Table 3. Only 18 species were found in all altitudinal intervals; they are the most common and abundant in the widespread plant communities: Aulacomnium palustre, A. turgidum, Ceratodon purpureus, Dicranum fuscescens, D. japonicum, Grimmia longirostris, Hylocomium splendens, Hypnum сирressiforme, Pleurozium schreberi, Polytrichum commune, P. juniperinum, P. piliferum, P. strictum, Rhytidiadelphus triquetrus, Rhytidium rugosum, Sanionia uncinata, Sphagnum angustifolium and Stereodon plicatulus. In total, 85 species were found above $1300 \mathrm{~m}$, and only 14 species are specific to this altitudinal belt. With decrease in altitude, the level of species richness increases; however, only 5 species are known exclusively at $700-1300 \mathrm{~m}$. The largest number of moss species, 257 , was registered at 350-499 m. In general, 276 species (89\% of the flora) occur below $700 \mathrm{~m}$ and 262 species (85\%) occur below $500 \mathrm{~m}$. As many as 166 species were found exclusively below $700 \mathrm{~m}$ altitude and 104 species below $500 \mathrm{~m}$. The most diverse moss flora is confined to the elevation from 350 to $499 \mathrm{~m}$, where 219 species ( $71 \%$ of the flora) grow and 60 of them are found only in this interval. It is remarkable that 195 species occur in the lowest altitudinal interval, 315-350 m, starting from the upper level of Zeysky Water Reservoir, with 38 species registered in the reserve and only found here.

The analysis of species distribution among the three altitudinal vegetation belts (Table 4) shows an even stronger altitudinal differentiation: there are only 9 species common to all hemiboreal, boreal and subalpine belts. These species are Abietinella abietina and Rhytidium rugosum, from predo-

Table 2. Bryophyte diversity in Zeysky State Nature reserve in comparison with other East Siberian and Far Eastern nature reserves (sources: Ignatov et al. 2004, Afonina et al. 2012, Bezgodov et al. 2013, Ignatova et al. 2013)

\begin{tabular}{|c|c|c|c|c|}
\hline Reserve & $\begin{array}{l}\text { Total area, } \\
\text { sq. km }\end{array}$ & Coordinates & $\begin{array}{c}\text { Altitudinal range, } \\
\text { m a.s.l. }\end{array}$ & Species number \\
\hline Zeysky Reserve & 1206 & $53^{\circ} 51^{\prime}-54^{\circ} 17^{\prime} \mathrm{N} 126^{\circ} 43^{\prime}-127^{\circ} 27^{\prime} \mathrm{E}$ & $315-1443$ & 310 \\
\hline Botchinsky Reserve & 2670 & $48^{\circ} 17^{\prime}-48^{\circ} 18.5^{\prime} \mathrm{N} 139^{\circ} 33^{\prime}-139^{\circ} 42^{\prime} \mathrm{E}$ & $30-1409$ & 239 \\
\hline Bureinsky Reserve & 3570 & $51^{\circ} 40^{\prime}-52^{\circ} 30^{\prime} \mathrm{N} 134^{\circ} 20^{\prime}-135^{\circ} 10^{\prime} \mathrm{E}$ & $550-2241$ & 278 \\
\hline Lazovsky Reserve & 1209 & $42^{\circ} 48^{\prime}-43^{\circ} 22^{\prime} \mathrm{N} 133^{\circ} 41^{\prime}-134^{\circ} 12^{\prime} \mathrm{E}$ & 0-1395 & 203 \\
\hline Norsky Reserve & 2111 & $52^{\circ} 3^{\prime}-52^{\circ} 8^{\prime} \mathrm{N} 129^{\circ} 8^{\prime}-130^{\circ} 4^{\prime} \mathrm{E}$ & $200-371$ & 251 \\
\hline Sokhondinsky Reserve & 2000 & $49^{\circ} 25^{\prime}-49^{\circ} 59^{\prime} \mathrm{N} 110^{\circ} 28^{\prime}-110^{\circ} 34^{\prime} \mathrm{E}$ & $600-2508$ & 276 \\
\hline Olyokminsky Reserve & 8451 & $58^{\circ} 04^{\prime}-59^{\circ} 20^{\prime} \mathrm{N} 58^{\circ} 45^{\prime}-58^{\circ} 53^{\prime} \mathrm{E}$ & 220-1206 & 212 \\
\hline
\end{tabular}


minantly dry habitats, the petrophytes Grimmia longirostris, Isopterygiopsis muelleriana and Poblia cruda, the widespread epiphyte Lewinskya sordida, the forest floor species Pleurozium schreberi and Sanionia uncinata, and Ceratodon purpureus growing on disturbed substrates and on coarse woody debris.

The greatest number of species, 271, is associated with the boreal belt, which has the greatest area and variety of habitats in the study area, including forest, rock and wetland habitats. $50 \%$ of the total number of species (155) occurs only within this belt. Among them, the most numerous are the species of forest habitats (Atrichum flavisetum, Brothera leana, Dicranum fragilifolium, Leucodon pendulus and Plagiomnium cuspidatum); bog mosses (Helodium blandowii, Polytrichum swartzii, Sphagnum capillifolium and S. flexuosum) and the alluvial species (Blindia acuta, Calliergonella lindbergii, Hygrobypnella polaris and Philonotis spp.).

In Zeysky Reserve, subalpine and hemiboreal belts occupy quite small areas and have a low diversity of habitats. There are almost no permanent watercourses and lakes. Only 73 species were found in the subalpine belt, of which only 14 are specific for this altitudinal level: Brachythecium erythrorrbizon, Bucklandiella microcarpa, B. nitidula, B. sudetica, Buxbaumia apbylla, Dicranum bardunovii, D. groenlandicum, D. pacificum, Paraleucobryum longifolium, Poblia lescuriana, Sphagnum imbricatum and $S$. perfoliatum.

A total of 90 species were found in the hemiboreal belt, among which 29 species are exclusively confined to it, growing mostly on cliffs rich in calcium compounds: Bryum argenteum, Encalypta pilifera, Entodon giraldii, Fabronia rostrata, Hondaella caperata, Plagiomnium acutum, Plagiopus oederianus, Podperaea krylovii, Ptychomitrium sinense, Seligeria tristichoides, Stereodon calcicola, Timmiella anomala, etc.

Table 3. Moss diversity from different altitudinal ranges.

\begin{tabular}{lcc}
\hline Altitudes, $\mathbf{m}$ & $\begin{array}{c}\text { Species number } \\
\text { \% f from total } \\
\text { number }\end{array}$ & $\begin{array}{c}\text { Incl. collected } \\
\text { only on these } \\
\text { range }\end{array}$ \\
\hline $1300-1442$ & $85 / 27$ & $14 / 5$ \\
$1000-1299$ & $85 / 27$ & $1 / 0.3$ \\
$700-999$ & $130 / 42$ & $4 / 1$ \\
$500-699$ & $175 / 56$ & $13 / 4$ \\
$350-499$ & $219 / 71$ & $60 / 19$ \\
$<350$ & $194 / 63$ & $38 / 12$ \\
\hline
\end{tabular}

\section{Phytogeoraphic relation}

Phytogeoraphic features of the flora are shown in Table 5. Three phytogeographic elements predominate the flora of Zeysky Reserve: multizonal (90 species, or $30 \%$ ), boreal-temperate (60 species, $19 \%$ ) and montain (53 species, $17.1 \%)$. They are followed by the boreal and arctomontane elements, hyparctic, hyparctomontane, temperate, suboceanic and xeric. Altitudinal belts mostly do not differ in spectra of such elements, except for boreal-temperate and temperate species. Boreal-temperate species (Callicladium haldanianum, Claopodium pellucinerve, Plagiomnium cuspidatum, Pylaisia selwynii) mainly associated with humid forests habitats comprise $12.3 \%$ in the subalpine belt and $13.7 \%$ in the boreal belt, but they are nearly absent in the hemiboreal belt. Temperate (Herpetineuron toccoae, Hondaella caperata, Leucodon coreensis, Ptychomitrium sinense) and xeric (Entosthodon pulchellus, Fabronia ciliaris, Syntrichia pagorum, S. sinensis) species are relatively more abundant in the hemiboreal belt $(5.6 \%$ in both cases) and absent from the subalpine belt.

The longitudinal spectra indicate a progressive decrease of circumpolar species from the subalpine to boreal and then hemiboreal belts from 79.5 to 76.0 and $65.4 \%$, respectively, and a concomitant increase of the number of Asian and Eurasian species. A similar pattern was found for mosses of the Northern and Western Palearctic (Ignatov 2001), as well as for vascular plants across altitudinal zonation in Zeysky Reserve (Dudov 2016); in the latter case, the percentage of East Asian species also significantly increased in the hemiboreal belt.

The fact that, in general, temperate mosses have less extensive ranges than boreal taxa can be shown in the following grouping of temperate species from Zeysky Reserve:

Circum-temperate: Haplocladium angustifolium, Entodon schleicheri, Heterophyllium affine, Homalia trichomanoides, Homomallium incurvatum, Hyophila involuta, Neckera pennata.

East Asian, disjunctive to eastern North America, some of them having localities in the tropics: Anomodon minor, Brothera leana, Grimmia pilifera, Helodium paludosum, Herpetineuron toccoae, Hyophila involuta, Pylaisia falcata, Pylaisiadelpha tenuirostris, Stereodon fauriei.

East Asian: Anomobryum nitidum, Anomodon thraustus, Brachythecium buchananii, Bucklandiella nitidula, Cryphaea amurensis, Dicranum japonicum, D. nipponense, D. pacificum, Drummondia

Table 4. Species diversity of Zeysky State Nature reserve from mountain altitudinal belts.

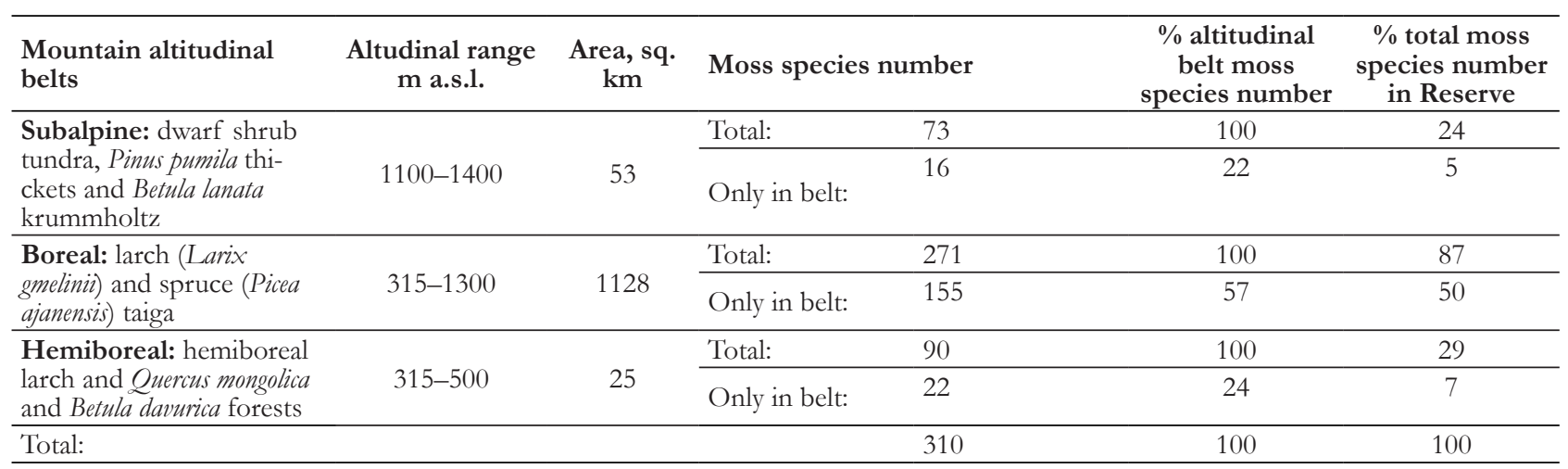


Table 5. Distribution moss species of Zeysky State Nature Reserve by geographic elements proposed by M.S. Ignatov (1993)

\begin{tabular}{|c|c|c|c|c|c|c|c|c|}
\hline \multirow{2}{*}{$\begin{array}{l}\text { Phytogeographic } \\
\text { category }\end{array}$} & \multicolumn{2}{|c|}{ Total in Reserve } & \multicolumn{2}{|c|}{ Subalpine belt } & \multicolumn{2}{|c|}{ Boreal belt } & \multicolumn{2}{|c|}{ Hemiboreal belt } \\
\hline & $\begin{array}{c}\text { Number of } \\
\text { species }\end{array}$ & $\begin{array}{l}\text { Percent of } \\
\text { flora }^{*}\end{array}$ & $\begin{array}{c}\text { Number of } \\
\text { species }\end{array}$ & $\begin{array}{c}\text { Percent of } \\
\text { flora }^{* *}\end{array}$ & $\begin{array}{c}\text { Number of } \\
\text { species }\end{array}$ & $\begin{array}{c}\text { Percent of } \\
\text { flora }^{* *}\end{array}$ & $\begin{array}{c}\text { Number of } \\
\text { species }\end{array}$ & $\begin{array}{l}\text { Percent of } \\
\text { flora }^{* *}\end{array}$ \\
\hline \multicolumn{9}{|c|}{ Zonal and altitudinal elements } \\
\hline Multizonal & 93 & 30.0 & 17 & 23.3 & 85 & 31.4 & 30 & 33.3 \\
\hline Arctomontane & 38 & 12.3 & 8 & 11.0 & 36 & 13.3 & 8 & 8.9 \\
\hline Montane & 53 & 17.1 & 16 & 21.9 & 45 & 16.6 & 18 & 20.0 \\
\hline Hyparctomontane & 3 & 1.0 & 2 & 2.7 & 2 & 0.7 & 1 & 1.1 \\
\hline Hyparctic & 6 & 1.9 & 3 & 4.1 & 6 & 2.2 & - & - \\
\hline Boreal & 40 & 12.9 & 16 & 21.9 & 49 & 18.1 & 22 & 24.4 \\
\hline Boreal-temperate & 60 & 19.4 & 9 & 12.3 & 37 & 13.7 & 1 & 1.1 \\
\hline Temperate & 6 & 1.9 & - & - & 4 & 1.5 & 5 & 5.6 \\
\hline Suboceanic & 6 & 1.9 & 2 & 2.7 & 4 & 1.5 & - & - \\
\hline Arid & 5 & 1.6 & - & - & 3 & 1.1 & 5 & 5.6 \\
\hline \multicolumn{9}{|c|}{ Longitudinal elements } \\
\hline Circumpolar & 227 & 73.2 & 58 & 79.5 & 206 & 76.0 & 59 & 65.6 \\
\hline Asian & 32 & 10.3 & 4 & 5.5 & 24 & 8.9 & 13 & 14.4 \\
\hline Asian-American & 27 & 8.7 & 8 & 11.0 & 22 & 8.1 & 10 & 11.1 \\
\hline Eurasian- American & 15 & 4.8 & 2 & 2.7 & 14 & 5.2 & 3 & 3.3 \\
\hline Eurasian & 9 & 2.9 & 1 & 1.4 & 5 & 1.8 & 5 & 5.6 \\
\hline Total & 310 & 100 & 73 & 100 & 271 & 100 & 90 & 100 \\
\hline
\end{tabular}

* Total species number in the Reserve

** Species number in altitudinal belt

sinensis, Entodon giraldii, Eurbynchiadelphus eustegia, Eurohypnum leptothallum, Fabronia rostrata, Glyphomitrium cf. bumillimum, Homomallium connexum, Hondaella caperata, Hypnum saitoi, Leucodon coreensis, L. pendulus, Myuroclada longiramea, Plagiomnium acutum, P. confertidens, Podperaea krylovii, Ptychomitrium sinense, Stereodon calcicola, Trachycystis ussuriensis, Ulota reptans, Zygodon sibiricus.

East Asian \& Western North American (Beringian sensu lato): Claopodium pellucinerve, Didymodon hedysariformis, Grimmia jacutica, Iwatsukiella leucotricha, Myuroclada maximowiczii.

This enumeration shows that temperate moss species in Zeysky Reserve are mostly of East Asian origin. Nevertheless, these element here is much poorer represented than in Primorsky Territory, as can be seen from comparison shown in Fig. 3. Cluster analysis (Ward's method, Euclidean distance) of 15 moss floras from eastern part of Asian Russia provides the following results:

Cluster 1 includes Manchurian bryofloras of SikhoteAlin Mts (floras SIK, LAZ) and Lesser Khingan Mts (KHI). There are 85-125 species in common with the flora of Zeysky Reserve (Fig. 4), and measures of inclusion of these bryofloras into the flora of Zeysky Reserve are 0.54-0.64 for the Sikhote-Alin flora and 0.75 for the Lesser Khingan, whereas measures of reverse inclusion are no more than 0.40 .

Cluster 2 encompasses the flora of Zeysky Reserve together with Norsky, Botchinsky, Bureinsky and Sokhondinsky reserves. There are 146-194 species in common, the measures of inclusion of the floras included into the analysis into the Zeysky Reserve flora were 0.69-0.73, and 0.480.63 for reverse inclusion.

Cluster 3 includes the floras of mountains of South and Eastern Yakutia (TS, UMA, MUS, ORU) and Stanovoe Upland (UDO). For these floras, 100-157 species are in common with the flora of Zeysky Reserve. At the same time,

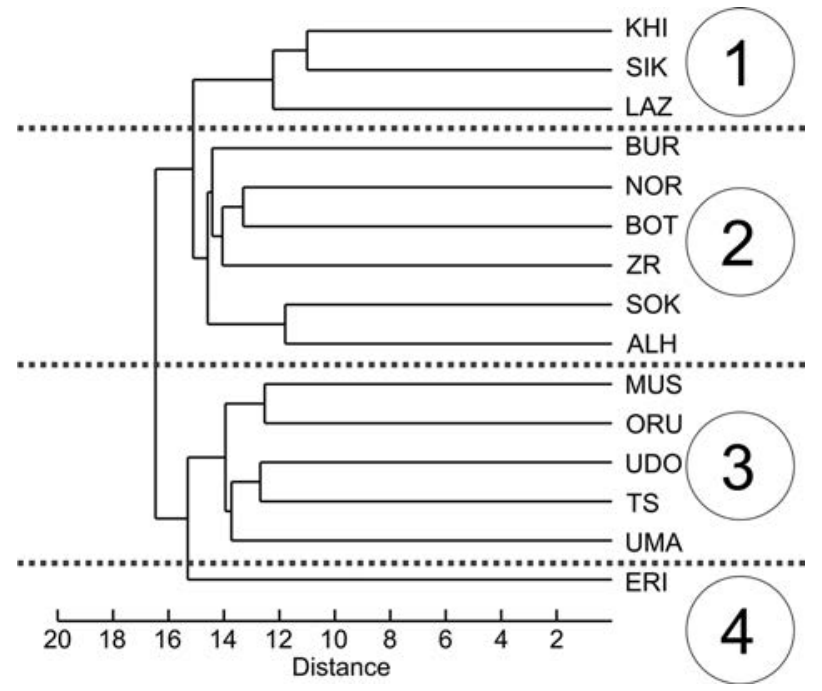

Figure 3 The results of cluster analysis (Ward's method, Euclidean distance) of East Siberian moss floras. The following data was used: - Zabaikalsky Territory: ALK - Alkhanay National Park (Afonina 2008, Afonina et al. 2017); SOK - Sokhondinsky State Reserve (Afonina et al. 2012); UDO - Udokan Range, Stanovoe Upland (Filin et al. 2015).

- Amur Province: KHI - Khingansky State Nature Reserve (Ignatov et al. 2004); NOR - Norsky State Nature Reserve (Bezgodov et al. 2013).

- Khabarovsk Territory: BOT - Botchinsky State Nature Reserve (Ignatova et al. 2013), BUR - Bureinsky State Nature Reserve (Ignatov et al. 2004).

- Prymorie Territory: LAZ - Lazovsky State Nature Reserve; SIK Sikhote-Alin Biosphere Reserve (Ignatov et al. 2004).

- Yakutia: MUS - Mus-Khaya Mt., Suntar-Khayata Range (Ignatova et al. 2011); ORU - Orulgan Range (Ignatov et al. 2014), TS Tokinsky Stanovik Range, Algama River basin (Stepanova et al. 1995); UMA - Yudomo-Mayskoe Upland, Ust-Maya District (Ignatov et al. 2001).

- Krasnoyarsk Territory: ERI - Eriechka River upper course, SE Taimyr (Fedosov et al. 2015) 


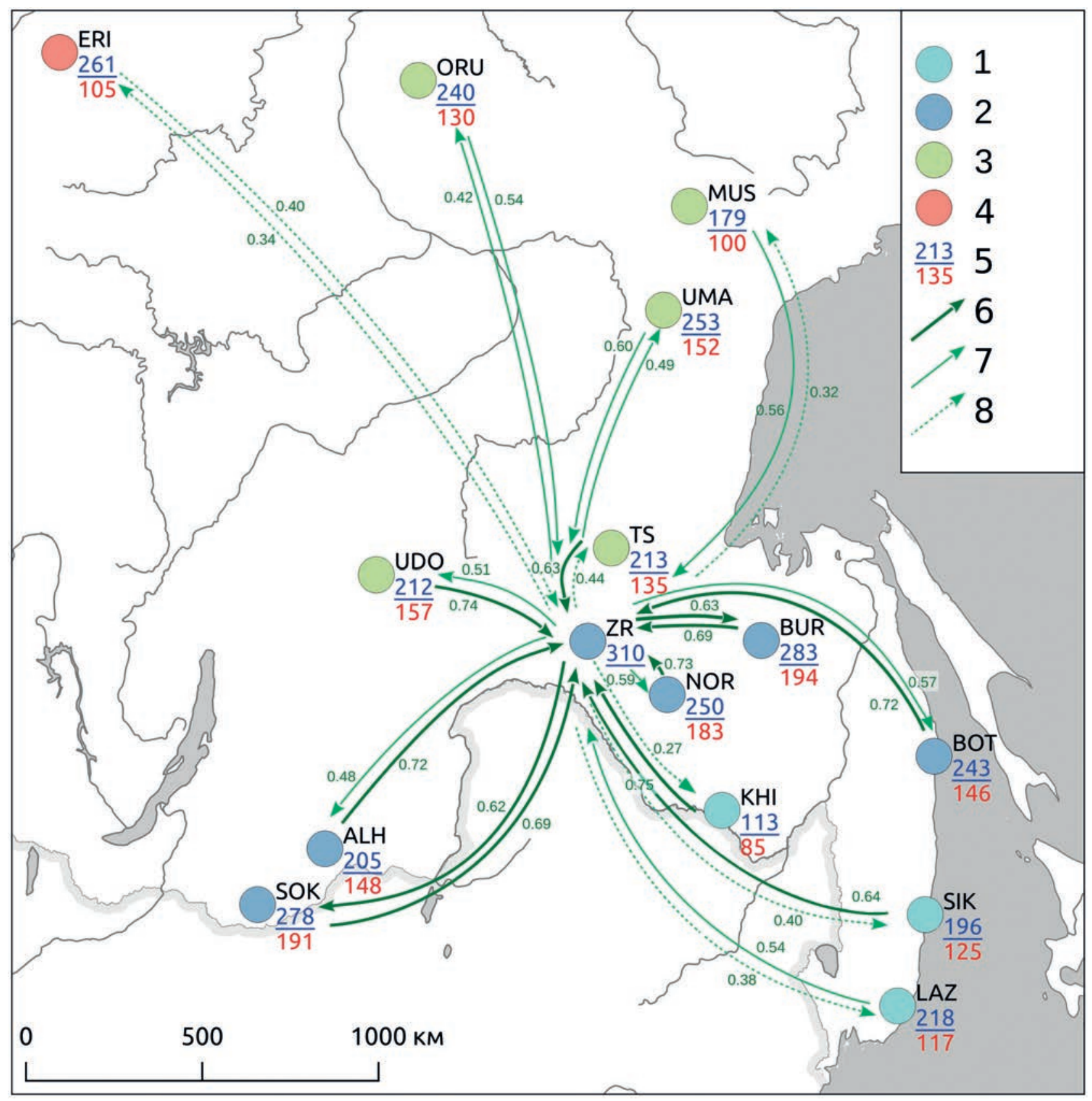

Figure 4 Similarity of the Zeysky Nature Reserve moss flora with Eastern Siberian and Far Eastern floras. 1-4 - Ward's clusters (see fig. 3). 5-6 - number of species in floras (blue type) and common one's. 7-8 - degree of similarity estimated using measures of inclusion (Yurtsev \& Semkin 1980): more 0.6, more 0.4 and less 0.6, less 0.4. For abbreviation of bryofloras see at fig. 3

$63 \%$ of species of the Tokinsky Stanovik Range and $74 \%$ of Udokan Range occur on Tukuringra Range as well. The Subarctic flora of Upper Course of Eriechka River, SouthEast Taimyr is found in cluster 4. There are 105 species in common with the flora of Zeysky Reserve (Fig. 4); less than $40 \%$ of species of the upper reaches of Eriechka River are present in the Zeysky Reserve flora. Phytogeographical differences between clusters 1 (South Primorsky Territory cluster) and 2 (Amur Province, south of Khabarovsk Territory \& north of Primorsky Territory cluster) were also discussed by Pisarenko \& Bakalin (2017). However, SouthEastern Transbaicalian bryofloras seem to be similar with the second cluster.
Therefore, the moss flora of Zeysky Reserve demonstrates a similarity to the moss floras along the border of the East-Asian and the Circum-Boreal floristic regions. Likewise the moss floras of Stanovoe and Bureinskoe Uplands and South-Eastern Transbaikalia, it is enriched by East-Asian elements, being in general of boreal type.

\section{Rare species}

Three species of mosses occurring in Zeysky Reserve are included in the Red Data Book of Russian Federation. All these species are associated with specific and rare habitats: metamorphic limestone cliffs (Hondaella caperata, Hyophila involuta) and spruce twigs in wet shaded parts of 
the mountain valleys (Cryphaea amurensis). It is important that the remaining population of the latter species remains stable, given the partial destruction of its habitat by the construction of Zeysky Water Reservoir.

\section{CONCLUSION}

High moss diversity in Zeysky Nature Reserve obviously corresponds to the presence of an apparent altitudinal zonation, rock diversity and its position at the junction between large phytogeographical districts. The species found only in the hemiboreal part of the reserve are largely of East Asian distribution, including three species from the Red Data Book of Russian Federation.

Stereodon calcicola has its westernmost localities in Zeysky Reserve, while some other East Asian flora elements are penetrating further to South Siberia, up to Baikal area (e.g. Entodon giraldii, Plagiomnium acutum) or even Altai (e.g. Brothera leana, Podperaea krylovii and Ptychomitrium sinense). It proves the role of Tukuringra Range as an important phytogeographical border not only for vascular plants but also for mosses. It also highlights the conservation value of the reserve as a hotspot of the bryophyte diversity.

\section{ACKNOWLEDGEMENTS}

We are grateful for the help during field work to Ksenia V. Dudova and staff of the Zeysky State Nature Reserve. Consultations in identification were received from D.Ya. Tubanova (Dicranum). We thank N. Lockhart for English correction of the manuscript. Russian Science Foundation, project no. 18-14-00121 supported our work in part in materials determination, data analysis and article preparation.

\section{LITERATURE CITED}

Abramova, L.I. \& D.A. Petelin 1981. Bryophytes. In: Flora and vegetation of Tukuringra range (Amur Oblast), (I.A. Gubanov, ed.), pp 64-85, Moscow State University Press, Moscow (in Russian). [Абрамова А.И., Петелин А.А. 1981. Мохообразные // ФАора и растительность хребта Тукурингра (Амурская область) / поА реА. И.А. Губанова. М.: ИзА-во Моск. Ун-та, С. 64-85].

Abramova, L.I., L.V. Bardunov, I.A. Gubanov, M.S. Ignatov, S.N. Korenyuk, V.S. Novikov, D.A. Petelin \& N.N. Steczura 1987. Bryophytes and vascular plants of Zeya Reserve (Flora and fauna of reserves in USSR). Moscow, 70 pp. (in Russian) [Абрамова А.И., БарАунов М.В., Губанов И.А., Игнатов М.С, Коренюк С.Н., Новиков В.С., Петелин А.А., Стецура Н.Н. 1987. Мохообразные и сосудистые растения Зейского заповеАника / ФАора и фауна заповедника СССР. М. 70 с.].

Afonina, O.M. 2008. Mosses of the «Alkhanai» National Park (Zabaykalsky Territory). Botanicheskii Zhurnal 93 (12): 1878-1896 (in Russian with English summary). [Афонина О.М. 2008. Мхи национального парка «А^ханай» (Забайкальский край) // Ботанический журнац. T. 93, №. 12. C. 1878-1896].

Afonina, O.M. \& E.A. Ignatova 2007a. A new species of Didymodon (Pottiacea, Musci) from Asian Russia. Arctoa 16:133-138.

Afonina, O.M. \& E.A. Ignatova 2007b. East Asian species of genus Stereodon (Brid.) Mitt. (Pylaisiaceae, Musci) in Russia. Arctoa 16: 7-20.
Afonina, O.M., Yu.S. Mamontov \& I.V. Czernyadjeva 2012. Mosses and liverworts of Sohondinskiy Strict Reserve. Publishing house of ETU, Saint-Petersburg, 200 pp. (in Russian). [Афонина О.М., Мамонтов Ю.С., Чернядьева И.В. 2012. Мхи и печеночники Сохондинского государственного заповедника. СПб. Иза-во СПбГЭТУ «ЭТИ», 200 с.].

Afonina, O.M., I.V. Czernyadjeva, E.A. Ignatova \& Yu.S. Mamontov 2017. Mosses of Zabaykalye Territory. Publishing house of ETU, Saint-Petersburg, 301 pp. (in Russian). [Афонина О.М., Чернядьева И.В., Игнатова Е.А., Мамонтов Ю.С. 2017. Мхи Забайкальского края. СПб.: ИзА-во СПбГЭТУ «АЭТИ», 301 с.].

Bakalin V.A., V.E. Fedosov, O.Yu Pisarenko \& E.A. Borovichev 2018. The bryophyte flora of northern Iturup (North-West Pacific): somewhere between the Circumboreal and East Asian Floristic Regions. Journal of Bryology. In press.

Bardunov, L.V. 2008. Hyophila involuta (Hook.) Jaeg. In: Red data book of Russian Federation (plants) (L.V. Bardunov, R.V. Kamelin, V.S. Novikov, eds.), pp. 630-631. KMK Scientific Press Ltd., Moscow (in Russian). [5apАунов А.В. 2008. Гиофила завернутая - Hyophila involuta (Hook.) Jaeg. // Красная книга Российской Федерации (растения) / под реА. А.В. Бардунова, Р.В. Камелина, В.С. Новикова. Москва: Товарищество научных изАаний КМК, С. 630-631].

Barinova, M.A. 1997. The reservoir effect on synusiae of mosses in Gilyuy River Valley: dissertation PhD of biology, Moscow State Pedagogical University, Moscow, 108 pp. (in Russian). [Баринова М.А. 1997. ВАияние водохранилища на синузии зеленых мхов Аолины Гилюя: Аисс. ... канА. биол. наук. М.: МГПУ, 108 с.].

Bezgodov, A.G., E.A. Ignatova \& M.S. Ignatov 2013. Checklist of mosses of Norskiy Rezerve. In: Collection of articles for the 15th anniversary of the Norsky reserve, (N.N. Kolobaev, ed.), pp. 59-78, Industrial-commercial publishing house Zeya, Blagoveshensk \& Fevralsk (in Russian). [Безгодов А.Г., Игнатова Е.А., Игнатов М.С. 2013. Список мхов Норского заповедника / Сборник статей к 15-летию Норского заповедника / под ред. Н.Н. Колобаева. Благовещенск-Февральск: ОАО «ПКИ «Зея», С. 59-78].

Brotherus, V.F., O.I. Kuzeneva \& N.I. Prokhorov 1916. List of mosses from Amur and Yakutsk Provinces. Trudy Botanicheskogo mureya Akademii nauk 16:1-71 (in Russian). [Бротерус В., Кузенева О., Прохоров Н. 1916. Список мхов из Амурской и Якутской областей / / Труды Ботанического музея Академии наук. Вып. 16. С. 1-71].

Cherdantseva, V.Ya. 2008. Hondaella caperata (Mitt.) Ando, B.C. Tan \& Z. Iwats. In: Red data book of Russian Federation (plants) (L.V. Bardunov, R.V. Kamelin, V.S. Novikov, eds.), pp. 618-619, KMK Scientific Press Ltd., Moscow (in Russian). [Черданцева В.Я. 2008. Хондаемла брахзитециевая - Hondaella caperata (Mitt.) Ando, B.C. Tan \& Z. Iwats.// Красная книга Российской Федерации (растения) / под реА. А.В. Бараунова, Р.В. Камелина, В.С. Новикова. Москва: Товарищество научных изданий KMK, C. 618-619].

Cherdantseva, V.Ya., O.Yu. Pisarenko, M.S. Ignatov, E.A. Ignatova, V.E. Fedosov, S.V. Dudov \& V.A. Bakalin 2018. Mosses of the southern Russian Far East, an annotated check-list. Botanica Pacifica 7(2):.........

Czernyadjeva, I.V. 2012. Mosses of Kamchatka Peninsula, Publishing house of ETU, Saint-Petersburg, 459 pp. (in Russian). [Чернядьева И.В. 2012. Мхи полуострова Камчатка. СПб.: ИзА-во СПбГЭТУ «АЭТИ», 459 с.]. 
Czernyadjeva, I.V., O.M. Afonina \& E.A. Ignatova 2015. The genus Anomobryum (Bryaceae, Musci) in Russia. Arctoa 24:459-470.

Dudov, S.V. 2016. Botanical geography of the Tukuringra Range (Zeya reserve a case study): dissertation $\mathrm{PhD}$ of geography, Moscow State University, Moscow, 179 pp. (in Russian). [Аудов С.В. 2016. Ботаническая география хребта Тукурингра (на примере Зейского заповедника): Аисс. ... канд. геогр. наук. М.: МГУ, 179 с.].

Dudov, S.V., O.M. Afonina \& E.A. Ignatova 2015a. Fabronia rostrata - a new species for the moss flora of Russia. Arctoa 24(2):416-418.

Dudov, S.V., E.A. Ignatova \& V.E. Fedosov 2015b. New moss records from Amur province. 2. Arctoa 24(1): 251-252.

Dudov, S.V., V.E. Fedosov \& M.N. Kozhin 2016. New moss records from Amur province. 3. Arctoa 25(2): 447-447.

Fedosov, V.E. \& G.Ya. Doroshina 2018. Orthotrichales In: Moss flora of Russia. Vol. 4. Bartramiales-Aulacomniales, (M.S. Ignatov, ed.), pp. 67-195, KMK Scientific Press Ltd., Moscow (in Russian and English). [Фелосов В.Э., Аорошина Г.Я. 2018. Порядок Orthotrichales - Ортотриховые / / ФАора Мхов России. Том. 4. BartramialesAulacomniales. M.: Товарищество научных изданий KMK, С. 67-195.

Fedosov, V.E. \& E.A. Ignatova 2011. Genus Bryoerythrophyllum P.C. Chen. In: Moss flora of Russia. Available from: http:/ /arctoa.ru/Flora/taxonomy-ru/taxonomy-ru.php. Last accessed 15.09.2018. [Федосов В.Э., Игнатова Е.A. 2011. Bryoerythrophyllum P.C. Chen - Бриоэритрофимлум // Фцора мхов России. Режим доступа: http://arctoa. ru/Flora/taxonomy-ru/taxonomy-ru.php. Запрос от 15.09.2018].

Fedosov, V.E. \& V.I. Zolotov 2008. New moss records from Taimyrsky Municipal District. 3. Arctoa 17: 212-215 (in Russian). [Федосов В.Э., Золотов В.И. 2008. Новые находки мхов в Таймырском муниципальном районе. 3. // Arctoa. Вып. 17. C. 212-215].

Fedosov, V.E., E.A. Borovichev, E.A. Ignatova \& V.A. Bakalin 2015. The bryophyte flora of Eriechka River upper course (SE Taimyr), with comments on the first record of Pseudoditrichum mirabile in Asia. Arctoa 24(1):165-186.

Fedosov, V.E., G.Ya. Doroshina, D.Ya. Tubanova, O.M. Afonina \& E.A. Ignatova. 2017. On four Orthotrichaceae species new for Russia. Arctoa 26(2):154-165.

Filin, V.R., E.A. Ignatova \& O.M. Afonina 2015. On the moss flora of Udokan range (Zabaikalsky Territory). Botanicheskii Zhurnal 100(8): 855-869 (in Russian with English summary). [Филин B.P., Игнатова Е.А., Афонина О.М. 2015. К флоре мхов хребта УАОкан (Забайкальский край) // Ботанический журнац. Т. 100, №. 8. С. 855-869].

Flatberg, K.I., O.M. Afonina, Yu.S. Mamontov, V.E. Fedosov \& E.A. Ignatova 2016. On Sphagnum mirum and S. olafii in Russia. Arctoa 25(1):96-101.

Gambaryan, S.K. 1977. Distribution of mosses on ecotopes of Zeya Reserve. In: Questions of geography of the Far East. Collection 17: biogeography of Priamurye, (A.I. Ivlev, ed.), pp. 61-77, Khabarovsk complex research Institute of FESC of Academy of Sciense USSR, Khabarovsk (in Russian). [Гамбарян С.К. 1977. Распространение мистостебельных мхов по экотопам Зейского заповедника // Вопросы географии Аальнего Востока. Сборник 17: биогеография Приамурья / под реА. А.И. Ивлева. Хабаровск: Хабаровский комплексный НИИ АНЦ АН CССР. C. 61-77].
Gambaryan, S.K. 1978a. About bryoflora of Zeya Reserve (Amur Oblast). In: Botanical researches in the Far East (S.S. Kharkevich, ed), pp. 20-25, Far East Scientific Centre of Academy of Science USSR, Vladivostok (in Russian). ГГамб̆арян С.К. 1978а. О бриофлоре Зейского заповедника (Амурская область) // Ботанические исслеАования на Аальнем Востоке / под ред. С.С. Харкевича. ВАаАивосток: АВНЦ АН СССР. С. 20-25].

Gambaryan, S.K. 1978b. New and rare mosses to Amur Oblast. In: Algae, fungi and mosses of the Far East (Z.M. Azbukina, ed), pp. 109-112, Far East Scientific Centre of Academy of Science USSR, Vladivostok (in Russian). ГГамбарян С.К. 1978b. Новые и редкие виды мхов Аля Амурской области // Водоросли, грибы и мхи Аальнего Востока / под реА. 3.М. Азбукиной. ВАаАивосток: АВНЦ АН СССР. С. 109-112].

Golysheva, L.F., D.A. Petelin \& N.G. Vasil'iev 1981. Vegetation. In: Flora and vegetation of Tukuringra range (Amur Oblast) (I.A. Gubanov, ed.), pp 167-228, Moscow State University Press, Moscow (in Russian). [Голышева $\Lambda . \Phi .$, Петелин А.А., Васильев Н.Г. Растительность // ФАора и растительность хребта Тукурингра (Амурская область) / под реА. И.А. Губанова. М.: ИзА-во Моск. Ун-та, С. 167-228].

Gotvanskiy, V.I. 1968. Relief of eastern part of Tukuringra Range. In: Geomorphological, landscape and biogeochemical studies in the Priamurye (A.S. Khomentovskiy, ed.), pp. 11-23, Nauka, Moscow (in Russian). ГГотванский В.И. 1968. Рельеф восточной части хребта Тукурингра // Геоморфологические, мандшафтные и биогеохимические исследования в Приамурье / под реА. А.С. Хоментовского. М.: Наука, 220 с.].

Gubanov, I.A., M.S. Ignatov, V.S. Novikov \& D.A. Petelin 1981. Vascular plants. In: Flora and vegetation of Tukuringra range (Amur Oblast) (I.A. Gubanov, ed.), pp 86-166, Moscow State University Press, Moscow (in Russian). ГГубанов И.А., Игнатов М.С., Новиков В.С., Петелин $\Lambda$.А. Сосудистые растения / / ФАора и растительность хребта Тукурингра (Амурская область) / под реА. И.А. Губанова. М.: ИзА-во Моск. Ун-та, С. 86-166].

Hedenäs, L. 2005. Oncophorus wablenbergii var. elongatus I. Hagen, an overlooked taxon in northern Europe. Lindbergia 30:32-38.

Ignatov, M.S. 1993. Moss diversity patterns on the territory of the former USSR. Arctoa 2:13-49.

Ignatov, M.S. 2001. Moss diversity in the Western and Northern Palearctic. Arctoa 10:219-236.

Ignatov, M.S. 2008. Cryphaea amurensis Ignatov. In: Red data book of Russian Federation (plants) (L.V. Bardunov, R.V. Kamelin, V.S. Novikov, eds.), pp. 609-610, KMK Scientific Press Ltd., Moscow (in Russian). [Игнатов M.C. 2008. Крифея амурская - Cryphaea amurensis Ignatov // Kрасная книга Российской Федерации (растения) / под ред. А.В. Бардунова, Р.В. Камелина, В.С. Новикова. Москва: Товарищество научных изданий КМК, С. 609-610].

Ignatov, M.S. \& V.Ya. Cherdantseva 1995. The families Cryphaeaceae, Leucodontaceae and Leptodontaceae (Musci) in Russia. Arctoa 4:65-104.

Ignatov, M.S. \& E.A. Ignatova 2013a. Genus Hymenostylium Brid. In. Moss flora of Russia. Available from: http:/ / arctoa. $\mathrm{ru} /$ Flora/taxonomy-ru/taxonomy-ru.php. Last accessed 15.09.2018. [Игнатов М.С., Игнатова Е.А. 2013a. РоА Hymenostylium Brid. - Гименостилиум // ФАора мхов России. Режим доступа: http://arctoa.ru/Flora/ taxonomy-ru/taxonomy-ru.php. Запрос от 15.09.2018]. 
Ignatov, M.S. \& E.A. Ignatova. 2013b. Genus Myurella Bruch, Schimp. \& Gümbel. In. Moss flora of Russia. Available from: http://arctoa.ru/Flora/taxonomy-ru/taxonomy-ru.php. Last accessed 15.09.2018. [Игнатов М.С., Игнатова E.A. 2013b. PoА Myurella Bruch, Schimp. \& Gümbel Миурелла // ФАора мхов России. Режим доступа: http://arctoa.ru/Flora/taxonomy-ru/taxonomy-ru.php. Запрос от 15.09.2018].

Ignatov, M.S. \& E.A. Ignatova 2017. Timmiaceae Schimp. In: Moss flora of Russia. Vol. 2. Oedipodiales-Grimmiales (M.S. Ignatov, ed.), pp. 216-226, KMK Scientific Press Ltd., Moscow (in Russian and English). [Игнатов M.C., Игнатова Е.А. 2017. Семейство Timmiaceae Schimp. Тиммиевые // Фцора Мхов России. Том. 2. Oedipodiales-Grimmiales / под ред. М.С. Игнатова. М.: Товарищество научных изданий КМК. С. 216-226].

Ignatov, M.S. \& R.H. Zander 1993. Barbula amplexifolia from Altai Mountains in Russia. The Bryologist 96(4):638-639.

Ignatov, M.S., E.I. Ivanova, E.A. Ignatova \& K.K. Krivoshapkin 2001. On the moss flora of Ust-Maya District (Republic Sakha/Yakutia, East Siberia). Arctoa 10:165-184.

Ignatov, M.S., E.A. Ignatova \& G.A. Pron'kina 2004. Mosses. In: The present-day state of biological diversity within protected areas. Issue 3. Lichens and bryophytes (O.M. Afonina \& N.S. Golubkova, eds.), pp. 274-366, IUCN - The World Conservation Union, Ministry of Natural Resources of the Russian Federation \& Commission on Biodiversity of the Russian Academy of Sciences, Moscow (in Russian and English). [Игнатов М.С., Игнатова Е.А., Пронькина Г.А. 2004. Мхи // Современное состояние биологического разнообразия на заповедных территориях России. Вып. 3. Аишайники и мохообразные / под реА. О.М. Афониной и Н.С. Голубковой. М.: МСОП - Всемирный союз охраны природы, Министерство природных ресурсов РФ, Комиссия РАН по сохранению биологического разнообразия. С. 274-366].

Ignatov, M.S., Isakova, V.G. \& E.A. Ignatova 2014. A contribution to the moss flora of Orulgan Range (Yakutia). Arctoa 23:194-206.

Ignatov, M.S., O.M. Afonina, E.A. Ignatova, A. Abolina, T.V. Akatova, E.Z. Baisheva, L.V. Bardunov, E.A. Baryakina, O.A. Belkina, A.G. Bezgodov, M.A.Boychuk, V.Ya. Cherdantseva, I.V. Czernyadjeva, G.Ya. Doroshina, A.P. Dyachenko, V.E. Fedosov, I.L. Goldberg, E.I. Ivanova, I. Jukoniene, L. Kannukene, S.G. Kazanovsky, Z.Kh. Kharzinov, L.E. Kurbatova, A.I. Maksimov, U.K. Mamatkulov, V.A. Manakyan, O.M. Maslovsky, M.G. Napreenko, T.N. Otnyukova, L.Ya. Partyka, O.Yu. Pisa $\neg$ ren $\neg$ ko, N.N. Popova, G.F. Rykovsky, D.Ya. Tubanova, G.V. Zheleznova \& V.I. Zolotov 2006. Check-list of mosses of East Europe and North Asia. Arctoa 15:1-130.

Ignatova, E.A. 2017a. Bucklandiella Roiv. In. Moss flora of Russia. Vol. 2. Oedipodiales-Grimmiales (M.S. Ignatov, ed.), pp. 327-346, KMK Scientific Press Ltd., Moscow (in Russian and English). [Игнатова E.A. 2017a. Bucklandiella Roiv. - Баклэндиельа // Фцора Мхов России. Том. 2. Oedipodiales-Grimmiales / под ред. М.С. Игнатова. М.: Товарищество научных изданий КМК, С. 327-346.

Ignatova, E.A. 2017b. Coscinodon Spreng. In. Moss flora of Russia. Vol. 2. Oedipodiales-Grimmiales (M.S. Ignatov, ed.), pp. 429-437, KMK Scientific Press Ltd., Moscow (in Russian and English). ПИгнатова E.A. 2017b. Coscinodon Spreng. - Косцинодон // Фцора мхов России. Том. 2. Oedipodiales-Grimmiales / под ред. М.С. Игнатова. М.: Товарищество научных изданий КМК, С. 429-437.

Ignatova, E.A. \& H.H. Blom 2017. Schistidium Brid. In: Moss flora of Russia. Vol. 2. Oedipodiales-Grimmiales (M.S. Ignatov, ed.), pp. 428-551, KMK Scientific Press Ltd., Moscow (in Russian and English). [Игнатова Е.А., Блом X.X. 2017. Schistidium Brid. - Схистидиум // Фцора мхов России. Том. 2. Oedipodiales-Grimmiales / под реА. М.С. Игнатова. М.: Товарищество научных изданий KMK, C. 428-551].

Ignatova E.A. \& J. Muñoz 2004. The genus Grimmia Hedw. (Grimmiaceae, Musci) in Russia. Arctoa 13:101-182.

Ignatova, E.A., E.I. Ivanova, O.V. Ivanov \& M.S. Ignatov 2011. Mosses of the Mus-Khaya Mountain (Yakutia, Asiatic Russia). Arctoa 20:211-226.

Ignatova, E.A., V.Ya. Cherdantseva \& O.V. Ivanov 2013. A preliminary list of mosses of the Botchinsky state nature reserve (Russian Far East). Arctoa 22:207-216.

Ignatova, E.A., L.E. Kurbatova, O.I. Kuznetsova, O.V. Ivanov, J.R. Shevock, B. Carter \& M.S. Ignatov 2015. The genus Scouleria (Bryophyta) in Russia revisited. Arctoa 24:47-66.

Ignatova, E.A., O.I. Kuznetsova \& M.S. Ignatov. 2017. Further comments on the genus Hedwigia (Hedwigiaceae, Bryophyta). Arctoa 26(2):132-143.

Ivanov, O.V., M.A. Kolesnikova, T.V. Akatova, O.M. Afonina, E.Z. Baisheva, A.G. Bezgodov, O.A. Belkina, I.V. Czernyadjeva, S.V. Dudov, V.E. Fedosov, E.I. Ivanova, E.A. Ignatova, M.N. Kozhin, E.D. Lapshina, A.A. Notov, O.Yu. Pisarenko, N.N. Popova, A.N. Savchenko, V.V. Teleganova, D.Ya. Ukrainskaya \& M.S. Ignatov 2017. The database of the moss flora of Russia. Arctoa 26(1):1-10.

Ivanova, E.I. \& M.S. Ignatov 2017. Polytrichopsida Doweld. In: Moss flora of Russia. Vol. 2. Oedipodiales-Grimmiales (M.S. Ignatov, ed.), pp. 40-114, KMK Scientific Press Ltd., Moscow (in Russian and English). [Иванова Е.И., Игнатов М.C. 2017. Kıасc Polytrichopsida // ФАора мхов России. Том. 2. Oedipodiales-Grimmiales / поА ред. М.С. Игнатова. М.: Товарищество научных изданий КМК, С. 40-114].

Ivanova, E.I., E.A. Ignatova, M.S. Ignatov, V.I. Zolotov \& K.K. Krivoshapkin 2005. Bryopsida. In: Diversity of plant life in Yakutia (N.S. Danilova, ed.), pp. 105-125, Siberian Branch of the Russian Academy of Sciences, Novosibirsk (in Russian). [Иванова Е.И., Игнатова E.A., Игнатов М.С., Золотов В.И., Кривошапкин К.К. 2005. Аистостебельные мхи // Разнообразие растительного мира Якутии / под реА. Н.С. Ааниловой. Новосибирск: Издательство СО РАН. С. 105-125].

Jamieson, D.W. 1976. A monograph of the genus Hygrohypnum Lindb. (Musci). Ph. D. Thesis. USA, The University of British Columbia. 425 pp. https://open.library.ubc.ca/ cIRcle/collections/ubctheses/831/items/1.0093875.

Kuzeneva, O.I. 1920. List of plants collected by the Zeya expeditions in the Amur region. Trudy botanicheskogo mureya Akademii nauk 18:26-92 (in Russian). [Кузенева О.И. Список растений, собранных Зейскими экспедициями в Амурской области // Труды ботанического музея Академии наук. Вып. 18. С. 26-92].

Nekrasov, I.A. \& I.V. Klimovskiy 1978. Permafrost zone of the Baikal-Amur Mainline, Nauka, Novosibirsk, 120 pp. (in Russian). [Некрасов И.А. Климовский И.В. Вечная мерзмота зоны БАМ. Новосибирск: Наука, 1978. 120 с.].

Pisarenko, O.Yu. \& V.A. Bakalin 2017 Moss diversity distribution patterns and agglomerates of local floras in the Russian Far East. Botanica Pacifica 6(2):21-33.

Sim-Sim, M., O.M. Afonina, T. Almeida, A. Désamoré, B. Laenen, C. A. Garcia, J.M. González-Mancebo \& 
M. Stech 2017. Integrative taxonomy reveals too extensive lumping and a new species in the moss genus Amphidium (Bryophyta). Systematics and biodiversity 15(5): 451-463.

Sochava, V.B. 1957. Zone features of vegetation in the area from Tukutingra Mt. Range to Anur River. Botanicheskii Zhurnal 42(2):195-210 (in Russian). [Сочава В.Б. 1957. Зональные черты растительного покрова на пространстве от хр. Тукурингра Ао Амура / / Ботанический журнал. Т. 42, № 2. С.195-210.

Stepanova, N.A., E.I. Ivanova \& K.A. Volotovskij 1995. Contributions to the bryoflora of Tokinskij Stanovik range (South Yakutia, East Siberia). Arctoa 4:35-44 (in Russian with English summary). [Степанова Н.А., Иванова Е.И., Волотовский К.А. 1995. Материалы к изучению бриофлоры хребта Токинский Становик (Южная Якутия, Восточная Сибирь) // Arctoa. Вып. 4. С. 35-44].

Yurtsev, B.A. \& B.I. Semkin 1980. Studies of concrete and partial floras with the aid of mathematical methods. Botanicheskii Zhurnal 65(12):1706-1718 (in Russian with English summary). [Юрцев Б.А., Семкин Б.И. 1980. Изучение конкретных и парциальных флор с помощью математических методов // Ботанический журнац. Т. 65, № 12. C. 1706-1718. 